Federal Reserve Bank of Minneapolis

Research Department Staff Report 477

December 2012

\title{
What Ever Happened to the Puerto Rican Sugar Manufacturing Industry?*
}

Benjamin Bridgman

Bureau of Economic Analysis

Michael Maio

University of Minnesota

and Federal Reserve Bank of Minneapolis

James A. Schmitz, Jr.

Federal Reserve Bank of Minneapolis

Arilton Teixeira

FUCAPE, Brazil

*We thank the members of the Research Library of the Federal Reserve Bank of Minneapolis-particularly Shawne Osborne-who have found, procured, and delivered many, many documents, reports, and so on for this project. We also thank Sam Brunell for excellent research assistance. The views expressed herein are those of the authors and not necessarily those of the Federal Reserve Bank of Minneapolis or the Federal Reserve System. 


\begin{abstract}
Beginning in the early 1900s, Puerto Rican sugar has entered the U.S. mainland tariff free. Given this new status, the Puerto Rican sugar industry grew dramatically, soon far outstripping Louisiana's production. Then, in the middle 1960s, something amazing happened. Production collapsed. Manufacturing sugar in Puerto Rico was no longer profitable. Louisiana, in contrast, continued to produce and grow sugar. We argue that local economic policy was responsible for the industry's demise. In the 1930s and 1940s, the local Puerto Rican government enacted policies to stifle the growth of large cane-farms. As a result, starting in the late 1930s, farm size fell, mechanization of farms essentially ceased, and the Puerto Rican sugar industry's productivity (relative to Louisiana) rapidly declined until the industry collapsed. The overall Puerto Rican economy also began to perform poorly in the late 1930s. In particular, Puerto Rico's per capita income was converging to that of the poorest U.S. states until the late 1930s, but since then it has lost ground to these states. One naturally wonders: was the poor overall performance of the Puerto Rican economy also the result of policy? We show that Puerto Rico embarked on other economic policies in the early 1940s that proved to be major setbacks to its economic development.
\end{abstract}

Keywords: Industrial policy; Land; Sugar; Puerto Rico JEL classification: L520, N560 


\title{
1 Introduction
}

\author{
Antagonistic interests must not fight the issues involved to the point of destroying \\ themselves, and Puerto Rico. \\ - Bird (1937)
}

When Puerto Rico became a U.S. possession in 1898, it had a very small sugar manufacturing industry. After Puerto Rican sugar was allowed into the United States tariff free in the early 1900s, its industry grew rapidly. While Puerto Rican sugar production was roughly one-fifth of Louisiana's in 1900, by 1930 its output was five times as great. Then, roughly 30 years later, in the middle 1960s, an amazing thing happened. Puerto Rico's sugar production plummeted. From 1965 to 1970, its output fell by roughly two-thirds (see Figure 1). Manufacturing sugar was no longer profitable for the Puerto Rican industry. Louisiana, in contrast, continued to produce and grow sugar.

This paper seeks to understand why the Puerto Rican sugar industry shriveled and died. Why is this an interesting question? First, the industry was important in its own right. In 1952, for example, the payroll of the sugar manufacturing industry accounted for 23 percent of total Puerto Rican wages. Not only were the industry's wages a significant share of island wages, the industry's jobs were well paying. Taxes paid by the industry accounted for a similar share of island taxes. Knowing why such an important industry collapsed is important.

Second, the performance of the Puerto Rican sugar industry began declining in the late 1930s. Puerto Rico's overall economic performance also turned poor in the late 1930s. From 1929 until the late 1930s, Puerto Rico's income per capita was converging to southern states like Mississippi, Alabama, and Arkansas. Given that Puerto Rico was fully integrated into the U.S. economy in the early 1900s, such convergence was to be expected. ${ }^{1}$ However, starting in the late 1930s, the convergence stopped: Puerto Rico's income per capita began

\footnotetext{
${ }^{1}$ For example, Puerto Rico has the same judicial, monetary, and tariff system as the United States.
} 
falling (relative to these states) and has not again achieved its late 1930s levels (see Figures A1-A3). ${ }^{2}$ It is in this sense that we say its performance has been poor from the late 1930s. So, the second reason to be interested is because one wonders: Was there a common factor for the poor performance of the Puerto Rican sugar industry and the overall Puerto Rican economy? Understanding the demise of Puerto Rico's stellar manufacturing industry (i.e., sugar manufacturing) may point us toward such factors.

What, then, led to the sugar industry's demise? One class of explanations is that market forces pushed up the price of local inputs to a point where manufacturing sugar was no longer profitable. For example, perhaps urban areas pushed into previous farmland, pushing up land prices. Or perhaps better opportunities in the United States, which led to migration, pushed up local sugar factory and sugar farm wages. These were not the reasons for the collapse.

Another class of explanations is that economic policy (federal and/or local policy) was behind the collapse. Federal policy was not responsible. In contrast, local economic policies directed at the sugar industry, enacted throughout the 1930s and 40s, damaged the industry and ultimately led to the industry's demise.

In exploring the impact of local policy on the sugar industry, we fortunately can contrast Puerto Rico's industry to other sugar manufacturing industries, like those in Hawaii, Florida, and Louisiana, which did not pursue the Puerto Rican policies. We mostly focus on Louisiana, since its industry was closest in structure (e.g., farm sizes) to Puerto Rico's industry.

Below we first list and describe some of the important economic policies directed toward the sugar industry in Puerto Rico. Second, we show that the policies had a major impact on how the industry was organized, for example, in terms of farm size and degree of mechanization. Third, we show that this organization led to very poor productivity growth, and ultimately to the industry's demise.

\footnotetext{
${ }^{2}$ In the Appendix we discuss Puerto Rico's per capita income performance relative to U.S. southern states over the period 1929-1985.
} 
As for local policies, the local government began a program to nationalize large farms, though this was abandoned. But this program was replaced with other policies that were designed to break up big farms, to discourage growth of farms, and to encourage entry of small farms. This was done in the face of strong evidence that large farms were more productive than small family farms.

Other policies directly increased the cost of mechanization. One such policy was tariffs on agricultural machines entering from the mainland. Other policies involved local government support for farm unions that resisted mechanization. ${ }^{3}$

When the policies were introduced in the mid-1930s, the average farm size in Puerto Rico was about 40 acres (and had been growing for the previous few decades). With the new policies, average farm size stopped growing and reversed course, falling to about 25 acres over the next few decades. In contrast, in Louisiana, which did not face the local Puerto Rican policies, average farm size grew rapidly over the same period. It was about 25 acres in the mid-1930s and climbed to 200 acres during the next 30 years. So, the movement in average farm size was vastly different in the two locations.

As for farm mechanization, both Louisiana and Puerto Rico had little mechanization in the early 1930s. In Puerto Rico, the same was true three decades later: very little of the industry was mechanized. In contrast, in Louisiana, by the mid-1960s most of the farm operations were mechanized. Again, there was a dramatic difference between the two locations.

With its farms shrinking, the land productivity record of the Puerto Rican industry was dismal from the mid-1930s to the mid-1960s. In the mid-1930s, land productivity in Puerto Rico was roughly 2.25 times greater than in Louisiana. By the mid-1960s, it was less than 1.5 times greater. Relative to Louisiana, then, Puerto Rican land productivity fell by nearly a third over the period.

With operations not being mechanized, the labor productivity record of the Puerto Rican

\footnotetext{
${ }^{3}$ While tariffs on machines and support for the unions would directly limit mechanization, the policies to limit farm size likely had an indirect impact as well (as we discuss below).
} 
industry was also dismal from the mid-1930s to the mid-1960s. In terms of labor productivity, Puerto Rico was nearly as productive as Louisiana at the end of World War II. But two decades later, its labor productivity was only 40 percent as great, a relative drop of over one-half.

The collapse of productivity in the Puerto Rican sugar manufacturing industry meant that profits also crashed, to the point where production was no longer viable. We think the history and economic analysis below provide a fairly strong argument that local economic policy killed the sugar industry in Puerto Rico.

To further explore the industry decline, we develop a quantitative model of the sugar industry. We construct a model of an industry in the spirit of Lucas (1978), in that there is a set of farmers that decide to be in the industry or not. Farmers differ in their skill in cane farming. They compare their profits in farming (which depend on skill) to their outside option. We argue that a "standard" version of the model can explain the collapse of the Puerto Rican sugar industry (and the continued growth of the Louisiana industry) if a key total factor productivity (TFP) parameter grows much faster in Louisiana than in Puerto Rico. We then explore whether the Puerto Rican policies can account for the divergence in TFP growth across the locations, a task we have not finished.

Given that the local government was such a detriment to this industry, one naturally wonders if this was true in other industries and brings us back to the question of a common factor: Was the general economic policy pursued by the Puerto Rican government in the 1930s and 1940s responsible for the economy's poor performance starting in the late 1930s? While this project began as a study of the sugar industry, we have been drawn to study industrial policy more generally in Puerto Rico. In the last part of the paper, we present some of this research. We describe many policies undertaken by the Puerto Rican government that were a significant obstacle to economic development. These policies may well have been the source of Puerto Rico's overall poor performance.

Why were the policies toward sugar adopted? We'll briefly discuss this and related issues 
throughout the paper, but one answer is that attacking large farms made for good politics. According to Descartes (1943, p. 400), "In practically all political campaigns [since 1900] land concentration and absenteeism [of owners] have been strongly attacked by all parties contending at the polls." Moreover, there was a "noteworthy agreement in the programs or platforms of all major parties in regard to . . . the desirability of the small, or family farm." 4

We start with a brief history of the industry's production in Section 2. We then briefly review related literature on the sugar industry in Section 3. Section 4 briefly outlines an extended list of possible reasons for the industry's collapse. We discuss local policy toward wages and big farms in Sections 5 and 6, respectively, and in Section 7 we discuss the consequences of that policy. In Section 8 we describe our quantitative model, in Section 9 two extensions of that model. In Section 10, we discuss other industrial policy programs in Puerto Rico in the 1940s, and we conclude our paper with Section 11. In the Appendix, we evaluate the economic performance of the Puerto Rican economy by comparing its performance to that in the U.S. states.

\section{History of Puerto Rican Sugar Production}

In this section, we briefly overview the history of the industry's production. We'll also discuss some of the major policy events that had an impact on the industry.

In manufacturing sugar, a factory processes sugar crops (either cane or beets) from farms that are nearly always a short distance away. The term "sugar manufacturing industry" includes both the factories and the farms that make the materials (i.e., crops) for the factories. When we talk about "production," sometimes the term will mean the finished product, namely, the processed sugar leaving the factory, sometimes the production on the farms. We'll try to be clear about this distinction below.

\footnotetext{
${ }^{4}$ The quote at the beginning of the paper, about antagonistic interests fighting issues to the point of destroying themselves, is from a report by Bird (1937, p. 4) on the Puerto Rican sugar industry. He was discussing fights in the 1930s over how local policy should treat the sugar industry. What he feared came to pass: the antagonistic interests fought until the industry died.
} 
Puerto Rico became a U.S. possession in 1898. Since that time, the Puerto Rican sugar manufacturing industry has been treated (with respect to U.S. federal policy) the same as mainland sugar manufacturers. When its sugar was allowed into the United States tariff free, Puerto Rican sugar production began to grow rapidly. One can see this in Figure 1, where we plot the production of sugar in Puerto Rico and Louisiana from 1880 to 2001. By 1930, Puerto Rico's production was roughly five times larger than Louisiana's.

Puerto Rico was a much cheaper location to manufacture sugar than Louisiana (in great part because of its better climate), and this was the reason for the growth in its size relative to Louisiana. Average costs of manufacturing sugar, over the 1929-30, 1930-31, and 1931-32 seasons, were $\$ 3.01$ for Puerto Rico and $\$ 4.51$ for Louisiana (per hundredweight [cwt.] of sugar; see U.S. Tariff Commission, 1934, Table 73). Though Puerto Rico had been rapidly expanding capacity since the early 1900s, its average costs were still significantly below Louisiana's. Its rapid rise in production was almost surely to continue, if not for the next policy change.

During the Great Depression, the U.S. government allowed the sugar industry to form a cartel. At the cartel's start, each U.S. sugar producing area (including Puerto Rico) was given a quota based on previous production levels. Foreign producers, which previously had faced only tariffs, were now given quotas as well (breaking the connection between the U.S. sugar price and world sugar price). Sugar production and quotas were slated to grow as the U.S. population grew over time, but Puerto Rico's soaring growth was not possible under the cartel. ${ }^{5}$

In the middle 1930s, another change in the policy environment emerged. While the mainland U.S. government had set local Puerto Rican economic policy before the 1930s, from this period onward the local government had more and more say about local policy toward the industry. It was during this time that it began enacting the policies we discuss below.

\footnotetext{
${ }^{5}$ We will describe some of the details of the cartel as we proceed.
} 
In the middle 1960s, as mentioned, an amazing thing happened: Puerto Rico's sugar production collapsed. It was not able to earn a profit selling sugar in the United States, though Louisiana's industry was. While the major collapse occurred in the mid-1960s, the Puerto Rican industry's peak production was 1952. Moreover, it was not filling its quota during some of the 1950s, and its official quota was being rolled back. So, the decline was well under way before the collapse.

A small bit of the industry continued to produce after the mid-1960s, but this was as a result of government subsidy. According to Suarez (1998), between 1968 and 1972, the local government provided significant subsidies to the industry. It finally nationalized the industry in 1973.

In 1974, the U.S. sugar cartel ended. There were no longer quotas on domestic production, though quotas on foreign producers remained. Hence, domestic producers, including those in Puerto Rico, are not limited in what they can produce and sell on the mainland. In principle, the Puerto Rican sugar industry can come back at any time. It was a very productive place to manufacture sugar before the 1930s (relative to, say, Louisiana, which has a big industry today), so why not today? Presumably, any potential investors expect the same treatment the industry received in the 1940s, described below, and stay away.

\section{Related Literature on the Puerto Rican Sugar Industry}

Surprisingly, there is almost nothing in the academic literature concerning the collapse of the Puerto Rican sugar industry. One exception is Suarez (1998), but she primarily discusses the industry's decline from the early 1970s on, when the industry had already been nationalized. She does present a list of some reasons for the decline of the industry in the 1960s (in the first paragraph of p. 25). There is no attempt, though, to analyze them.

Some of the reasons on Suarez's list may have played a role (like union resistance to 
new technology), but others don't make sense. One such factor is increased competition from Cuba and the Dominican Republic. There was in reality no competition from these countries. The U.S. industry was a cartel that gave quotas to Puerto Rico and other domestic areas (and to foreign producers). Puerto Rico could not fill these quotas. We mention this only because one sees this explanation ("too much competition" from Cuba and others) in economic histories of the island.

While we have found very little in the academic literature discussing the collapse, there were industry observers in the 1930s (and later) who voiced concerns for the industry's survival. When a local commission was set up in 1934 to plan the future economic development of the island, key features of the plan were to nationalize part of the sugar industry (both farms and factories), to promote small farms, and to make laws that forbade farms from going beyond a certain size (see Report of the Puerto Rico Policy Commission, 1934, referred to as the Chardon Report). Some called this plan, and related ideas, a recipe for disaster, voicing these concerns in newspapers, trade journals, and publications of trade associations. In a series of newspaper articles in El Mundo during September and August 1938, entitled $L a$ Ruina De La Industria Azucarera, Coll Cuchi (1938) argued that it would be a big mistake to break up big farms, as they were the most efficient. He also argued that land concentration was much greater in other parts of the United States, like Hawaii, than in Puerto Rico.

The Puerto Rican trade association published a lengthy report (Association of Sugar Producers of Puerto Rico, 1940) that responded to the proposed policies to limit farm size and to nationalize some of the large farms. Part of the report documented the efficiency of large farms. In Figure 2, we plot the yield of sugar per acre by cane-farm size. ${ }^{6}$ As shown, there is a monotonically increasing relationship between cane-farm size and land yield, with

\footnotetext{
${ }^{6}$ The definition of farm is from the USDA. A cane-farm is a farm where sugarcane is the primary crop. Most cane-farms have nearly all their land in cane, so the cutoff is not of importance. Cane-farm size is measured either by acres planted to cane or by acres of cane harvested in a given year. Acres planted is bigger than acres harvested if (1) some of the crop had to be abandoned or (2) the farm plants cane that grows for a period longer than a year. Finally, sugar produced on an acre equals the tons of cane harvested multiplied by the percentage of sucrose in the cane.
} 
the largest farms producing nearly twice as much per acre as the smallest farms. ${ }^{7}$

This difference in land yield is likely due, in part, to larger farms having better land. But the large farms in Puerto Rico also employed more intensive land use methods. Better cultivation, more irrigation, and more scientific farming methods (such as use of commercial fertilizers) were used. The report presents the costs per acre of growing sugarcane for various expenses. It gives a breakdown by colony (individual) and company farms. Cultivating charges were twice as large per acre on company farms; irrigation costs were 76 percent as large; and fertilizer costs were 21 percent higher. ${ }^{8}$

Yield per acre is only a partial measure of productivity. But the report (pp. 76-77) also lists the opinion of experts in farming and sugar manufacturing as to the overall efficiency of large farms. For example, a U.S. Department of Interior report on Hawaii in the early 1940s, states,

The United States has no other example of efficiency in farming that can equal that of the Territory [Hawaii] . . . . This high efficiency is due to the advance industrialization of sugar and pineapple farming. Hawaii has adopted the corporation form of organization in agriculture and has proved it to be a sound economic base for high standards of living for its people.

Hawaii's farms were very large and productive. For the years 1947-49, Hawaii's labor productivity (tons of sugar per fieldworker hour) was 4.5 times greater than Puerto Rico's. Over the next two decades, Hawaii's labor productivity grew much faster than Puerto Rico's. For the years 1967-69, labor productivity was 8.1 times greater in Hawaii than Puerto Rico (see Garrott (1971), Table 2, p. 20). These differences are, of course, extremely large and also important: below we show that labor's share of revenue on sugarcane farms in Puerto Rico was 50 percent.

\footnotetext{
${ }^{7}$ The source for this figure is Table IV (in the Appendix) in Association of Sugar Producers of Puerto Rico (1940). The table is from the USDA, Agricultural Adjustment Administration, Sugar Section.

${ }^{8}$ Association of Sugar Producers of Puerto Rico (1940, p. 70, Table 19) The original source for the table is U.S. Tariff Commission (1934). Costs are reported for the years 1930-31 and 1931-32. We have averaged the expenditures over the two years.
} 
In addition to documenting the efficiency of large farms, the report also discussed the failure of previous experiences with nationalization of farms (see discussion, "Failure of Collective Farming," pp. 100-113).

\section{Candidates for the Collapse}

In this section, we'll briefly go through an extended list of possible reasons for the industry's collapse. We'll conclude that local Puerto Rican economic policy was the culprit.

\subsection{Market Forces Pushing Up Land Prices}

One potential explanation for the industry's demise is that land prices rose to levels at which industry profits were no longer possible. Perhaps cities expanded into land that was previously used for sugarcane, or the land was employed in more profitable agriculture. None of this happened. In fact, when the sugarcane farms were closed, the land typically turned to forest. ${ }^{9}$

The growth in Puerto Rico's forests has, in fact, attracted much academic interest. This literature provides land cover maps that are of interest. For example, Kennaway and Helmer (2007) present land cover maps for Puerto Rico in 1951 (on p. 361) and 2000 (on p. 364). In 1951, land in sugarcane farms is spread throughout the island, as is land in coffee farms and tobacco farms. ${ }^{10}$ There was very little forest cover.

In 2000, the island was covered with forest. There were trivial amounts of land in any agriculture. The land devoted to sugarcane farms (and the other farms) was now primarily forest and pasture (inactive agriculture).

So, far from land prices soaring, the evidence indicates that the value of land over most

\footnotetext{
${ }^{9}$ While expansion of the urban area around San Juan clearly led to the closing of some farms, this was a very small share of the land that was abandoned.

${ }^{10}$ Perloff (1950) presents data (Table 20, p. 82) showing Puerto Rico with 1,022,000 acres in crops in 1945. Among the big crops, sugar amounted to 302,000 acres, coffee 180,000, tobacco 56,000, and starchy veggies 231,000 .
} 
of the island had fallen so much that it was best abandoned (i.e., returned to forest).

\subsection{Market Forces Pushing Up Local Wages}

Perhaps market forces pushed up the price of farm labor to the point where farming was not profitable. Maybe the sugar industry had to compete for labor with industries in the United States (because of opportunities for migration), increasing Puerto Rican wages to levels where farming was not profitable.

While free mobility of labor between Puerto Rico and the mainland was always allowed, there were reductions in the (relative) cost of migration to the United States after World War II. And migration did increase significantly in the 1940s and 1950s.

But migration (and other market forces) were not determining wages in the Puerto Rican sugar industry. There were mandated minimum wages for cane workers, and there is good evidence that these were binding (see discussion below).

\subsection{Federal Economic Policy}

We have already discussed some aspects of U.S. federal policy toward the Puerto Rican sugar industry. The two most important policies were (1) allowing the industry, beginning in the early 1900s, to sell to the mainland tariff free and (2) allowing the U.S. sugar industry, in 1934, to form a cartel. Neither of these caused the collapse.

Another potentially important piece of federal policy concerned wages. We'll first discuss farmworker wages, then factory wages.

The U.S. legislation that allowed the creation of the U.S. sugar cartel in 1934 (i.e., the Sugar Act) had a provision for paying sugar farmworkers a minimum wage, and Puerto Rican cane farmers were bound by these regulations.

In 1938, the U.S. government passed the Fair Labor Standards Act (FLSA), which established minimum wages for industries engaged in interstate commerce. Federal minimum wages did not (and still do not) apply to agricultural workers, so this law had no impact on 
Puerto Rican farmworker wages.

Shortly after the FLSA was passed, the local Puerto Rican government passed a minimum wage law (Law No. 8, 1941) to encompass industries not covered by the FLSA, like local agriculture, retail, construction, and so on. This 1941 law also applied to sugar fieldworkers. Hence, from the early 1940s, minimum wages for sugar workers were set by the local government.

In summary, then, federal policy was not responsible for the collapse.

\subsection{Local Economic Policy}

A very long list of local economic policies had an adverse impact on the sugar industry. We'll briefly give an overview of these policies here. In Section 5, we'll discuss wage policy in detail. In Section 6, we'll discuss in detail those policies that had the greatest negative impact on the industry - those destroying large farms.

One way to group policies is according to those that were (primarily) directed at sugar factories and those (primarily) directed at sugar farms. We'll start with policies directed at factories.

\section{Policies directed at sugar factories}

Roughly 40 factories processed sugarcane into sugar in the late 1930s. In 1942, the local government passed a law making the factories a public utility. In particular, "Act 221 declared that sugar factories were affected with a public interest and gave the Public Services Commission jurisdiction over them" (Martinez, 1952-53, p. 391). With this Act, the factories were subject to rate of return regulation. Section 68 called for the commission to set fees for factory services so that factories earned no more than a 5 percent return on capital. ${ }^{11}$

Making the sugar factories into a public utility was a fairly important and unusual event.

\footnotetext{
${ }^{11}$ The constitutionality of this Act was challenged by factories in the courts. In the meantime, a new Act (Act 426) was passed in 1951. The industry continued to be a public utility under this Act, but it seems control over the factories was less severe.
} 
On the mainland, an industry is designated a public utility if it consists of a single producer, having a monopoly on local sales, like an electric utility — not industries that have 40 factories (and many firms) and export most of their product.

Not only was it unusual to extend the concept to such an industry, the Public Service Commission of Puerto Rico had much more power to intervene in factory operations than a mainland public service commission. Commission employees were given wide authority to regulate the operations of factories. ${ }^{12}$

Other policies had a negative impact on factories, like the policy that limited work to eight-hour shifts and mandated minimum wages, but in the end we think the most detrimental policies to the industry were those that affected large farms. So, we focus on those policies in this paper and turn to give a brief overview of them.

Policies directed at sugar farms

A whole series of policies were detrimental to large farms. First, there was a policy to nationalize large farms. This program was begun in the early 1940s but was stopped after a few years. Its negative impact, though, likely lasted until the industry collapsed. Some other programs meant that large firms had difficulty expanding (if they wanted to), while others increased the cost of mechanization. We think that it is these policies that had the biggest negative impact and which we'll focus on in Section 6.

But first let us talk briefly about wages.

\section{$5 \quad$ Local Policy toward Wages}

As we mentioned, minimum wages were set by the local insular board. ${ }^{13}$ We explore two issues. First, were the minimum wages binding? We think they were. Second, did they have

\footnotetext{
${ }^{12}$ See, for example, the Annual Report of the Public Service Commission (Government of Puerto Rico, 1949-50), which documents factory operational changes mandated by commission employees. Affected factories included Central Cayey and Roig.

${ }^{13}$ In practice, there was a transition from wages being set under the Sugar Act to being set by the local government. While the insular board was set up in 1941, the USDA was involved with wages until the mid-1950s.
} 
a large impact on the sugar industry's demise? We think that the impact was minor.

Were they binding? We compare wages in the Puerto Rican sugar industry to other local wages. We argue that the differences are so big that it's hard to imagine that they represented compensating differentials for working in sugar.

To compare wages, we use data from the State Insurance Fund of Puerto Rico (Government of Puerto Rico, 1952-53), which lists the median daily wage for the 50 most important classifications (or industries) in the year (see Exhibit 8). The median daily wages are comparable in that there was an eight-hour day in Puerto Rico.

Sugarcane farmworkers earned a median daily wage of $\$ 3.27$. Other farming wages included coffee $\$ 1.44$ and pineapples $\$ 2.14$. Cane workers earned significantly more. ${ }^{14}$ Did these differences reflect compensating differentials? One concern is that there was not a full season in cane. But cane workers had longer seasons than those in other crops. Average employment in cane was 8.7 months, in coffee 6.8 months, and in tobacco 5 months (see Perloff, 1950, p. 146). In addition, a special employment security program, only for cane workers (discussed below), provided benefits for nine weeks during the slow season. The benefit was roughly one day of pay per week. In 1952-53, the benefit was $\$ 27.51$ (see Government of Puerto Rico, Annual Report of the Commissioner of Labor, 1952-53, p. 83). So, to earn this benefit, a coffee farmworker would have to work 27.51/1.44 weeks, or 19 weeks.

Cane labor was likely more arduous than other farming. But it's hard to imagine that the wage discrepancy between coffee and cane was the result of compensating differentials resulting from this. ${ }^{15}$

This evidence suggests that wages were mandated by the local minimum wage board. But there is also another possibility. Sugar workers in Puerto Rico were organized into unions.

\footnotetext{
${ }^{14}$ Cane farmer wages also exceeded the wages in manufacturing industries that were the biggest employers: cloth $\$ 2.50$, needlework $\$ 2.61$, and concrete construction $\$ 3.25$. It also paid better than industries like retail $\$ 2.51$.

${ }^{15}$ Sugar factory workers were highly paid, at $\$ 5.60$. Only 3 of the 50 industries paid more: tallymen $\$ 6.12$, stevedoring $\$ 6.16$, and cement manufacturing $\$ 6.16$. The first two occupations are longshoring jobs in the ports. So, the only three classifications that paid higher wages had very strong unions. Engineers had the same median wage $(\$ 5.60)$ as sugar factory workers. Sugar factory workers were paid more than professional workers (Colleges - Professional Employees $\$ 5.02$ and Hospitals - Professional Employees \$4.62).
} 
These unions were involved in resisting mechanization and pushing for higher wages. So, the unions may deserve some credit. To the extent they do, we must also give credit to another Puerto Rican policy. As discussed below, Puerto Rican policy was much more conducive to unions than in the mainland.

How big was the impact of wages on the collapse? We can use the model below to ask how much rising wages led to the demise.

We define the real wage in the industry as the average money wages paid to fieldworkers (per hour) divided by the price that farmers received for sugarcane. ${ }^{16}$ So, this is the real input cost facing the farmers hiring labor. After World War II, the average real wage in Puerto Rico was roughly 50-60 percent of the wage in Louisiana. The real wage in both locations roughly doubled over the next 20 years, so the relative wage across locations did not change much. In Figure 3, we plot the real fieldworker wage in Puerto Rico relative to Louisiana, for the period 1946-1973.

Though we do not introduce the model until below, it's not surprising that if we use the real wages in the model, the path of wages cannot explain the divergence in output and productivity between Puerto Rico and Louisiana (since the growth in real wages is the same in the two locations). This is what we mean by wages not having much of an impact.

What is a puzzle is that in the model as the real wage facing farmers increases, we expect increased use of capital and mechanization. This happened in Louisiana, but not Puerto Rico. And that's because of the Puerto Rican policies that really mattered and to which we now turn.

\section{Local Policy toward Big Farms}

Here we will list and describe policies. Then we argue that the policies had a big impact on how the industry was organized. Some policies hurt large farms directly. Other policies encouraged the growth of small farms, indirectly hurting large farms (as we describe below).

\footnotetext{
${ }^{16}$ The data are from the USDA's Sugar Statistics.
} 


\subsection{Land Reform}

In 1941, the Puerto Rican legislature passed the Land Law of Puerto Rico (see Descartes, 1943, p. 399). This law made it illegal for corporations to own farms greater than 500 acres. It also created a public Land Authority to buy corporate farms that exceeded 500 acres. These farms were then turned into public farms and managed by the Land Authority.

While the Land Authority started this process, it ran out of funds to purchase farms soon thereafter (with about 10 percent of total farm land in public hands). ${ }^{17}$ While the Land Authority stopped buying farms, it continued managing the new public farms. ${ }^{18}$

It is interesting to note that Puerto Rico, given its integration into the U.S. economy, was in a different position than other Latin American countries that nationalized parts of agriculture. First, Puerto Rico is part of the U.S. judicial system; hence, it had to pay close attention to market prices for the land. Second, Puerto Rico is part of the U.S. Federal Reserve System; hence, it did not print its own currency. We strongly suspect that if the Puerto Rican government could have paid less than market prices for the farms and/or was able to print currency, the experiment of nationalizing farms would have lasted longer than it did.

So, this Land Law alone did not destroy the industry. The industry was around for another two decades before it collapsed. However, it likely had a big negative impact. Some farmers may have been wary of expanding their farms beyond the 500 -acre cutoff. The government might again try to punish farms above 500 acres and this time might use another mechanism. In fact, it did try. In 1959 the governor of Puerto Rico proposed to tax any corporation $\$ 10,000$ if it owned a farm above 500 acres (Edel, 1963, p. 41).

In Figure 4, we present evidence that farmers may have been wary of expanding farms. For a given year, we take all farms that were above 200 acres in size and plot the fraction

\footnotetext{
${ }^{17}$ Below we discuss the reasons why the local government ran out of funds for the farm nationalization program.

${ }^{18}$ There were also plans to create small farms from these nationalized farms, but these plans were mostly dropped.
} 
of farms between 200 and 500 acres and the fraction greater than 500 acres. ${ }^{19}$ We do this for the years 1935 and 1955. One sees that the fraction of large farms over 500 acres was smaller in 1955 than in 1935.

We also make this comparison between Louisiana and Puerto Rico for the year 1955. In Figure 5, one sees that in 1955 the fraction of large farms over 500 acres was smaller in Puerto Rico than in Louisiana. ${ }^{20}$

Figures 4 and 5 provide some evidence that Puerto Rican farmers were wary of expanding beyond 500 acres. Hence, while the land reform stopped in the 1940s, the fear of similar laws and policies seems to have put an implicit tax on farm expansion beyond 500 acres. But the next policy meant that large farms might not be able to expand at any cost. ${ }^{21}$

\subsection{Small Farms Have First Claim to Quota}

When the U.S. sugar cartel started in 1934, quotas were given to both firms owning the factories (on sales of sugar) and farmers (on the amount of acres they could plant to sugar crops). While the dispersal of firm quotas was done at the federal level, the assignment of farmer quotas was handled at the local level.

The assignment of farmer quotas in Puerto Rico was much different from that in any other U.S. producing area. In other areas, like Louisiana, farmers owned their quota. They could not sell the quota but could rent it to other farmers. There essentially was no entry of new farmers.

In Puerto Rico, farmers who had not produced cane before were free to enter, as long as

\footnotetext{
${ }^{19}$ The data for these farm counts are for Puerto Rico, 1935: same source as Figure 2. For Puerto Rico, 1955: from the U.S. Department of Agriculture (1963), Table 53, p. 61. Note that these are the bins we are given. Also, the 1935 source is planted acres, the 1955 source harvested acres.

${ }^{20}$ The data for these farm counts are from the U.S. Department of Agriculture (1963). For Puerto Rico, 1955: Table 53, p. 61. For Louisiana, 1955: Table 34, p. 45. Louisiana is planted acres.

${ }^{21}$ As for the history of land restrictions in Puerto Rico, some of the initial U.S. legislation establishing civilian government in Puerto Rico (Foraker Act, 1900) put limits on land ownership by corporations (the limit was 500 acres). There are debates about why this restriction was included. But as far as enforcement, the law was ignored until an island-born attorney general, in 1936, stated his intention of strictly enforcing the law. The legality of the law was fought for six years, by which time the Puerto Rican legislature had passed its own law in 1941, the Land Law of Puerto Rico (see Descartes, 1943, p. 399).
} 
they entered at a small scale. ${ }^{22}$ They could not rent the quota, however, but had to farm it.

This policy (assigning quota to every small farmer who wanted one) was a potential setback for large firms. Any quota given to small farms meant that large farms had less quota. This meant that large farms would have fewer opportunities to expand. In fact, their quota could be reduced.

There are a number of reasons why a farmer would take this deal, that is, enter with a small quota (when he would not have entered before the cartel's restrictions on acres). First, the cartel prices were no longer tied to the world price and remained strong. Second, as part of the cartel agreement, there were side payments sent to farmers for abiding by the quotas. $^{23}$ These payments were large, as much as 25 percent of the revenue farmers received from selling crop to factories. Third, the local government put in place many policies that reduced the production cost of small farms (see below).

And there was an influx of small farms. One way to see this is by looking at average farm size. In Figure 6, we plot the average cane-farm size in Puerto Rico and Louisiana. We see that average farm size significantly declines in Puerto Rico when the cartel started in the mid-1930s, from roughly 40 acres to 25 acres. It does not grow after that. Average farm size soars in Louisiana.

The share of acres in big cane-farms also declined significantly from the 1930s in Puerto Rico. In 1935, the share of acres accounted for by farms exceeding 500 acres was 60 percent; in 1954, the share had declined to 23 percent. ${ }^{24}$

\footnotetext{
${ }^{22}$ Farms that had not produced before could enter and receive a minimum allotment of 10 tons raw value. (Federal Register 14, p. 3441, June 24, 1949.) Since small farms in Puerto Rico produced around 2 tons of sugar an acre, this worked out to around a 5-acre allotment.

${ }^{23}$ These side payments were sent from the factories that processed foreign sugar in the mainland's major cities (see Bridgman et al.).

${ }^{24}$ For 1935, the reference is the same as for Figure 2. For 1954, the reference is the PMA testimony. PMA citation: United Packinghouse, Food, and Allied Workers records, Wisconsin Historical Society Archives, Mss 118, Box 542, Folders 1-3.
} 


\subsection{Crop from Small Farms Processed First}

The Puerto Rican government passed a law that required factories to process the sugar crops of small farmers as they arrived at the factories. This law hurt large farmers (and benefited small ones) because a farmer wants his cane processed as quickly as possible, as sugarcane begins to lose sugar content once cut. Small farmers in essence could move to the front of the line.

Such a law would be a problem if there was a coordination problem between farmers and factories. And there was.

There is a best time to plant sugarcane and hence a best time to harvest cane (when its sugar content is highest). Given harvested cane loses sucrose as time progresses, there is a period when factory processing capacity is in great demand. But the capacity is limited, so the fixed capacity needs to be allocated across farmers. Before this new law, private contracts between farmers and factories would specify the details of when a farmer could have his cane processed, but this law usurped these contracts.

\subsection{Wage Policy Favors Small Farms}

While we showed that the path of average real wages faced by farmers in Puerto Rico and Louisiana grew at roughly the same rate after World War II, the wages that large farms paid in Puerto Rico were higher than the wages of small farmers. This was because of compensation benefits (beyond wages) that Puerto Rican law provided for fieldworkers on large farms. These benefits were not given in Louisiana.

First, there was a workmen's (injury) compensation plan for sugar workers in Puerto Rico beginning in 1935. If farms were bigger than a certain size in employment (typically four employees), they paid into an insurance fund. In 1952, the rate was $\$ 4.05$ per $\$ 100$ in wages (see Government of Puerto Rico, State Insurance fund of Puerto Rico (1952-53), Exhibit 5).

Second, there was an employment security plan established in 1948 for the sugar industry 
(Act 356). Some workers experienced downtime during the year. This Act provided compensation during this period. Workers were typically given a day's pay for each week they were idle, for as much as nine weeks.

This employment security plan was funded by an excise tax on sugar produced by the farms. Farmers with less than 300 cwt. of sugar produced were exempt. These were fairly small farms as well. With a yield of two tons of sugar per acre, a farm of 7.5 acres would meet this threshold. In 1950-51, the employment security contributions were 6.3 percent of industry wages. Since some farms paid wages but did not make contributions to the fund, the contribution by large farms may have been 7 to 8 percent of their wages.

These two programs, then, meant that large farms paid as much as 12 percent more for wages than small farms.

The policies described in the first four subsections, on land reform, small firms having first dibs on quota, processing small farms first, and wages, led to farms being smaller than they would have been without the policies. Given that there are scale economies in mechanization (Holmes and Mitchell (2008), Holmes and Lee (2012)), this would mean less mechanization. But there were also policies that directly led to less mechanization, policies described in the next two subsections.

\subsection{Tariffs on Farm Machines and Farm Intermediates}

Since Puerto Rico was integrated into the U.S. economic and legal system, in theory there should be no tariffs on goods shipped from mainland producers to the island. But in practice there were. Agricultural machinery and agricultural intermediate goods (like fertilizer) were subject to excise taxes at the docks in Puerto Rico. These could be as much as 20 percent of landed value (see, e.g., Koenig (1953)).

These tariffs limited the use of intermediates and machinery. As we discussed above in Section 3, large farms typically used more intermediates than small farms, so these tariffs hurt large farms. 
We'll discuss the evidence on mechanization in the next subsection.

\subsection{Farmworker Unions}

Labor laws and policy in Puerto Rico were much more conducive to union organizing than in the United States. We first discuss these differences and then their consequences.

First, there were new U.S. labor laws passed during the Great Depression. However, U.S. agricultural workers were excluded from the major New Deal labor laws. In contrast, the Puerto Rico Labor Relations Act (1945) extended the New Deal laws, such as the Wagner Act, to Puerto Rican agricultural employees (Galvin 1976).

Second, U.S. state laws made union organizing more difficult. In 1956, Louisiana passed a right-to-work law for agricultural workers.

Third, Puerto Rico provided financial support to unions, such as help setting up their organizations. For example, there was a Bureau of Labor Union Accounting, which helped unions set accounting systems for their organizations. ${ }^{25}$

As a consequence, in part, all attempts to organize mainland sugar fieldworkers failed (Scott and Jones 1974). Unionizing of sugar workers in Puerto Rico had success. In fact, there were unions of sugar workers dating to 1903 (Galvin 1976). One activity of the unions was to resist mechanization on the farms.

While union resistance to labor-saving techniques was strong, it is hard to quantify the impact they had on mechanization. But one contemporary observer thought they played a big role. When discussing unions on the island, Ross (1957, p. 91) states that "the only . . . effective labor unions are those which represent vested interests opposed to progress: the longshoremen, fighting for the continuation of costly hand-loading techniques that increase Puerto Rico's economic distance from the job-giving mainland; the sugar workers fighting every step in the inevitable and overdue mechanization of the sugar industry."

To the extent that Puerto Rican laws led to the growth of unions that were successful in

\footnotetext{
${ }^{25}$ See, e.g., the Annual Report of the Commissioner of Labor, pp. 114-115, 1961.
} 
resisting technology, the impact was greater on the larger farms.

Let's turn to the evidence on mechanization. Let's first start with the factories. In the mid-1930s, Puerto Rico had some of the most technologically advanced factories among U.S. sugar producers. One measure that is highly correlated with the state of technology is the size or capacity of a factory. In 1937-38, the average daily mill output in Puerto Rico was 26,271 tons of sugar, in Hawaii 24,437 tons, and in Louisiana 6,424 tons (Association of Sugar Producers, 1940). Average factory capacity in Puerto Rico was nearly four times that in Louisiana. Many of the factories in Puerto Rico were new (built in the 1920s), and the most recent technology was brought to Puerto Rico. Hence, mechanization was not an issue before the local government began to dominate local policy.

Next, let's consider mechanization in farming. Mechanization of farming required technological breakthroughs that were only beginning to emerge in the 1930s. Hence, there was very little mechanization in either Puerto Rico or Louisiana in the early 1930s. But there was a big divergence over the next 30 years.

Three primary areas of farming could be mechanized: the planting (and weeding) of cane, the harvesting of cane, and the loading of harvested cane onto trucks (and/or trains). As for harvesting, Smith (1966, p. 48) reports that in 1966 less than 5 percent of the crop was mechanically harvested in Puerto Rico. Mechanical harvesting was quickly adopted in Louisiana. By 1946, 80 percent was harvested mechanically, and by 1960, the share exceeded 90 percent (U.S. Department of Agriculture (1961)). In terms of loading harvested cane, the U.S. Department of Labor (1969) reports that only 26 percent of the crop was mechanically loaded in 1960. It reports that this fraction had increased to 69 percent in 1969, but the industry was only a small shell of itself at that date. For Louisiana, Burrows and Shlomowitz (1992) describe mechanical loading as common in Louisiana by 1940 .

So, there was very little mechanization of cane farming in Puerto Rico relative to Louisiana. 


\section{Consequences of Policy: Productivity and Profits}

The policies directed at the sugar industry led to smaller farms, and to very little mechanization. We now examine the consequences of such choices for productivity in the industry.

\subsection{Land Productivity}

As we noted earlier, large cane-farms had a higher yield per acre than smaller cane-farms. So as the average cane-farm size grew in Louisiana relative to Puerto Rico, we would expect to see land productivity in Puerto Rico fall relative to Louisiana. As Figure 7 shows, that is exactly what happened. The figure shows the tons of sugar produced per harvested acre in Puerto Rico relative to Louisiana, over the period 1941-1973. The data are quite volatile because of bad crop years resulting from hurricanes and other natural causes, so we smooth the series by taking a five-year moving average. Land productivity is more than two times as high in Puerto Rico than in Louisiana throughout much of the 1940s, but the ratio falls steadily throughout the rest of the period to 1.3 .

\subsection{Labor Productivity}

One symptom of the failure of the Puerto Rican sugar industry to mechanize is falling labor productivity on Puerto Rican cane-farms relative to their counterparts in Louisiana. Figure 8 shows labor productivity in Puerto Rico relative to Louisiana, using sugar produced per fieldworker man-hour as the productivity measure. Labor productivity in Puerto Rico was over 80 percent of the level in Louisiana in the early 1950s, but its relative productivity fell below 40 percent by the late 1960s.

\subsection{Labor's Share of Revenue}

Next, we consider labor's share of revenue in the industry, here defined as the wage payments by farmers to fieldworkers divided by farmer revenue from crop sales to factories. The lack of 
mechanization on Puerto Rican sugar farms is also reflected in labor's relatively high share of revenue in the Puerto Rican industry.

In the 1930s, sugarcane farming was a very labor-intensive process. Our data start in the late 1940s, when Puerto Rico's labor share is in the mid-50s and Louisiana's in the mid-40s (see Figure 9). Louisiana's introduction of machinery seems to have already reduced labor's share by the late 1940 s. $^{26}$

Over the next two decades, Puerto Rico's share fell from the mid-50s to 50 percent. Louisiana's fell from the mid-40s to 30 percent. Throughout the period, the average fieldworker share in Puerto Rico is 0.52 , compared to 0.32 in Louisiana.

\subsection{Summary}

We think that the historical and economic analyses presented above provide a reasonably convincing argument that the sugar industry's demise was the result of local economic policy. To achieve a better understanding of the process, we also develop a quantitative model below. We'll talk about profits in the context of the model. But it should not be surprising that profits in cane farming in Puerto Rico were falling relative to those in Louisiana, and at some point farmers' alternative opportunities dominated making sugar.

\section{Basic Model}

Here we explore whether we can generate the demise of the Puerto Rican sugar industry in a quantitative model. We have made some good progress on this question, though we are not done.

We argue that a "standard" version of the Lucas model can explain the collapse of the

\footnotetext{
${ }^{26}$ In both locations, the value of cane output includes Sugar Act payments to farmers. Additionally, we do not include nonwage compensation such as unemployment insurance or workmen's compensation payments in calculating fieldworker wages, which will bias labor's share downward. And since nonwage compensation accounted for a larger portion of worker wages in Puerto Rico than in Louisiana, the difference in labor's share of revenue between the two locations is larger than it appears in Figure 9.
} 
Puerto Rican sugar industry (and the continued growth of the Louisiana industry) if a key TFP parameter grows at a much faster rate in Louisiana than in Puerto Rico. We then explore extensions to the model that might explain this divergence in TFP.

We start with a model of how the Puerto Rican industry worked when the United States operated under a tariff system. We'll extend it to discuss how the industry operated under a quota. The model in this section is simply a decision problem faced by potential farmers. It will also be a static problem.

\subsection{Environment and Decision Problem}

Farmers decide to enter the industry or pursue an outside opportunity. Given the price of sugar (the world price plus a tariff) and the prices of inputs (which are assumed not to depend on the industry), potential farmers calculate the profits they would earn farming. They compare this to their outside option.

The set of potential farmers each has a farm skill indexed by $s \in\left[s_{\min }, s_{\max }\right]$. They also have an outside option, or skill, indexed by $z \in\left[z_{\min }, z_{\max }\right]$. Let $H(s, z)$ be the cumulative distribution function (CDF). We'll assume independence of skills, that is, $H(s, z)=F(s) G(z)$. The total mass of potential farmers is $N$.

For now, we assume that $G(z)$ is a degenerate distribution; that is, there is only a single $z$.

A farmer of type $s$ produces with the constant elasticity of substitution (CES) technology

$$
y=A_{y} s^{\gamma}\left[\frac{\beta}{1-\gamma}\left(A_{l} \cdot l\right)^{\mu}+\frac{1-\beta-\gamma}{1-\gamma}\left(A_{n} \cdot n\right)^{\mu}\right]^{\frac{1-\gamma}{\mu}},
$$

where $y$ is output (say, tons of sugar per acre), $l$ is land input, and $n$ is farm input (farmworkers). Note that for now, we do not include capital.

The parameter $\mu, \mu \in(-\infty, 1)$ determines the elasticity of substitution between land and

farm labor, which equals $1 /(1-\mu)$. So, if $\mu=0$, we have unit elasticity (Cobb-Douglas). If 
$\mu<0$, then the elasticity is less than one (and substitutability is less than Cobb-Douglas).

Let $r$ and $w$ denote the rental rate for land and the wage rate for farm labor. Let $p$ denote the price of sugar. Conditional on entering farming, an individual would solve

$$
\max _{l, n} \pi=p \cdot y-r \cdot l-w \cdot n,
$$

given the production function above.

The two first-order conditions are

$$
p \cdot \frac{\partial y}{\partial l}=r
$$

and

$$
p \cdot \frac{\partial y}{\partial n}=w .
$$

From these we can solve for the choices, which we denote $l^{*}(r / p, w / p, s)$ and $n^{*}(r / p, w / p, s)$, and then output $y^{*}(r / p, w / p, s)$. We denote maximum profits by $\pi^{*}$, where profits are in dollars.

Each potential farmer draws a $(s, z)$ (remembering there is only a single $z$ at this point). Assume the outside opportunity is denominated in dollars. Then a person farms if

$$
\pi^{*}=p \cdot y^{*}-r \cdot l^{*}-w \cdot n^{*} \geq z
$$

and does not farm otherwise, that is, if $\pi^{*}<z$. Let $d^{*}(r / p, w / p, s, z / p) \in\{0,1\}$ denote the decision to farm (with $d^{*}=1$ the choice to farm).

Imagine that there is such a model for Puerto Rico and one for Louisiana. Input prices may differ by location, as well as TFP parameters, like $A_{l}$, since Puerto Rico has better land and climate. 


\subsection{Definition of Model Statistics}

Let's now calculate model statistics corresponding to data presented above. Farm size for a given farmer is simply $l^{*}(r / p, w / p, s)$. Farm size is increasing in skill $s$. To calculate average farm size, let $L^{*}$ denote demand for land, where

$$
L^{*}=N \cdot \iint_{d^{*}(.)=1} l^{*}(r / p, w / p, s) d F(s) d G(z) .
$$

Though there is only a single outside option, $z$, we have used a general notation since it will apply to the case where $G(z)$ is not degenerate.

Let $M^{*}$ denote the number of farmers, where

$$
M^{*}=N \cdot \iint_{d^{*}(.)=1} d F(s) d G(z)
$$

Then average farm size is given by

$$
\bar{l}=L^{*} / M^{*}
$$

Labor productivity of an individual farmer is $y^{*} / n^{*}$. The formula is

$$
\frac{y^{*}}{n^{*}}=\frac{1}{1-\beta-\gamma} \cdot \frac{w}{p} \cdot\left[\frac{\beta}{1-\gamma}\left(\frac{\beta}{1-\beta-\gamma} \frac{A_{l}}{A_{n}} \frac{w / p}{r / p}\right)^{\frac{\mu}{1-\mu}}+\frac{(1-\beta-\gamma)}{1-\gamma}\right] .
$$

Notice labor productivity does not depend on $s$. So, industry labor productivity is the same as farmer labor productivity.

Let total output of the industry be denoted $Y^{*}$, with

$$
Y^{*}=N \cdot \iint_{d^{*}(.)=1} y^{*}(r / p, w / p, s) d F(s) d G(z) .
$$




\subsection{Real Input Prices}

Our first exercise is to plug in the time series (for Puerto Rico and Louisiana) of input prices $w / p$ and $r / p$ into the formula (3) above. We will keep the other parameters fixed and examine the labor productivity time series generated by the model. We generate the time series by simply stringing together a sequence of static problems where only the real input prices are changing. In particular, we assume that each potential farmer draws a pair $(s, z)$ in the initial period and keeps that pair over time.

Let's first ask how labor productivity in the model depends on real input prices, $w / p$ and $r / p$. Then we turn to the data on these prices.

How does labor productivity depend on $w / p$ ? In the expression for labor productivity (3), there are two terms with the real wage, $w / p$. One of the terms has an exponent of one. The other has an exponent of $1 /(1-\mu)$. Since $\mu<1$, this exponent is positive. Hence, labor productivity is increasing in the real wage.

How does labor productivity depend on $r / p$ ? The exponent on real land cost $r / p$ in the expression (3) is $-[\mu /(1-\mu)]$. Since $(1-\mu)>0$, the exponent is positive if $\mu<0$. If the two inputs are less substitutable than in the Cobb-Douglas case, then labor productivity and real land costs move together.

What is a good estimate for $\mu$ ? Most estimates of substitutability between inputs in agriculture are industry-level estimates. The substitutability for a given crop will be less than that at the industry level. At this point, we think that $\mu<0$ is a reasonable assumption. We'll present evidence later.

Here we will focus on the relative time series (Puerto Rico relative to Louisiana) generated by the model. Recall Figure 3, where the real wage in Puerto Rico did not change much relative to Louisiana from the mid-1940s to the mid-1960s. This suggests that using the two real wage series in the model, with all else fixed, will not lead to a divergence in labor productivity between the two locations. ${ }^{27}$

\footnotetext{
${ }^{27}$ Notice that if $\mu=0$, the Cobb-Douglas case, then labor productivity is proportional to the real wage.
} 
It is much harder to get data on the real opportunity cost of land, or the rental rate, $r / p$. However, we can say some qualitative things. In Puerto Rico, most of the farmland was returned to forest, implying that the real opportunity cost of land, $r / p$, was falling. So, we can say that the ratio of $r / p$ in Puerto Rico to that in Louisiana was very likely getting smaller over time. In the model, this means that labor productivity falls in Puerto Rico relative to Louisiana. So, qualitatively, labor productivity would be diverging in the two locations.

But now consider the model statistics for output. Using the real input prices in the model implies that output in Puerto Rico grows faster than Louisiana. ${ }^{28}$ Let's call this issue 1.

Next consider the model statistics for average farm size. Using the real input prices in the model implies that average farm size in Puerto Rico grows faster than Louisiana. Let's call this issue 2 .

\subsection{TFP and Outside Option}

Our next exercise is to ask: Can we change other model parameters over time so that the model statistics better match the data?

Again, we will string together a series of static problems. We'll consider changes in two parameters: the productivity parameter for labor, $A_{n}$, and the value of the outside option, $z$. We assume that each potential farmer draws a pair $(s, z)$ in the initial period (note that $z$ is still fixed). Now, we'll let the outside option grow over time. That is, if a potential farmer draws the outside option $z$ in the initial period, then the value of his outside option over time is $\theta^{t} \cdot z$. Next, we let the productivity parameter be $\rho^{t} \cdot A_{n}$.

So, we ask: what kind of differences in the parameters $\theta$ and $\rho$ across the two locations could help explain the data?

Suppose $\theta_{P R}>\theta_{L A}$. This draws farmers out of sugar in Puerto Rico. This obviously helps with issue 1 (output growing faster in Puerto Rico than Louisiana). But it draws the If $\mu<0$, then it is not.

${ }^{28}$ Of course, output is set by quota, but after some point, Puerto Rico does not fill its quota. 
smallest skilled farmers out, exacerbating issue 2 .

Suppose $\rho_{L A}>\rho_{P R}$. This would help with issue 1 and issue 2 (as long as $\mu<0$ ). So, this difference in TFP growth rates would work qualitatively.

In initial calibration work, we estimate that $\rho_{L A}$ must be about four times larger than $\rho_{L A}$ to match some of the key statistics, like labor productivity divergence.

But this leads to a puzzle: why would there be such dramatic differences in TFP growth rates? Let's first add policy to the model.

\subsection{Restriction of Farm Size}

Let's introduce policy. Let's simply say that you cannot be above a certain size $l^{\max }$ in Puerto Rico (see, e.g., Guner, Ventura and Yi (2008), García-Santana and Pijoan-Mas (2011), and Adamopoulos and Restuccia (2011)).

What happens? In the model as is, the highest skilled guys don't leave. In fact, under some conditions, no farmer type leaves (this is due to the partial equilibrium framework).

Industry output decreases and average farm size decreases, but there is no change in labor productivity. The labor productivity formula does not change.

We now turn to adding some additional features to the model.

\section{Model: Extensions}

We very briefly discuss two features.

\subsection{Distribution of Outside Options}

Suppose now that the distribution $G(z)$ is not degenerate. So, at the initial date, a potential entrepreneur draws a pair $(s, z)$.

Now say that you cannot be above a certain size $l^{\max }$ in Puerto Rico. In this version, there is a different qualitative result: The highest skilled guys leave. 
Industry output decreases and average farm size decreases, but there is no change in labor productivity. The labor productivity formula does not change.

But let's extend the model further. Suppose that the TFP parameter $A_{n}$ is some function of average skill of farmers, $\bar{s}$, call it $A_{n}(\bar{s})$. The most skilled guys are likely the farmers to read the experiments with fertilizers and so on. That is, suppose there are spillovers of learning from them. Then when we limit size, we push out the high skill, and we can explain differences in TFP.

\subsection{Scale Economies in Capital or Adoption}

Let's talk about capital in the model. We have talked about mechanization a lot in the data, of course.

Suppose we put capital into the model in a standard way. In particular, suppose we had an aggregator of capital and labor, with say, Cobb-Douglas substitution. Then this composite is used with land, as in the technology above. At this point, we do not think this extension (with, say, tariffs on capital) will deliver the divergence in labor productivity.

But if we have a model where there are some scale economies, as in Holmes and Mitchell (2008) and Holmes and Lee (2012)), then this would deliver labor productivity differences.

\section{More on Early Puerto Rican Industrial Policy}

In this section, we'll briefly discuss other industrial policy programs that were launched by the local Puerto Rican government in the 1940s.

\subsection{Creating State-Owned Industrial Sector}

We begin with the government's strategy to create a state-owned industrial sector. Starting in the early 1940s, it nationalized several public utilities (water, transport, and energy). It then constructed state-owned manufacturing factories in cement, glass, shoes, paper, and 
clay products (see Bel (2009)). This was a bold strategy, with the goal of creating a staterun economy (recall that the local government had started nationalizing large sugar farms as well).

Like the program to nationalize farms, this program was dumped by the end of the decade. For one thing, the state-owned companies were losing money. The local government realized it would not have enough funds to continue this program (see Bel (2009), p. 25). Stateowned factories were sold or closed. As we mentioned above for the land "reform" program, we strongly suspect that this experiment would also have lasted longer if the government had been able to print currency.

This nationalization program must be considered a major setback for Puerto Rico's economic development. First, the government devoted a significant amount of public funds to a program that made little sense from the beginning. As for its sensibility, Ross (1957, pp. 88-90), for example, discusses the government's plans for the shoe factory and describes the folly of the idea that the factory could provide shoes for the entire population. It is both a biting and humorous critique. ${ }^{29}$ As for the magnitude of the funds, the contributions to public enterprises went from $\$ 135,000$ in $1939-40$ to $\$ 30,572,000$ in $1945-46$. In $1945-46$, the contributions to public enterprises amounted to 29 percent of total government expenditures (see Perloff (1950), Table 95, p. 379). ${ }^{30}$ Obviously, the government could not continue to spend 29 percent of its budget to support inefficient, money-losing public enterprises.

\footnotetext{
29 "[P] erhaps the best illustration of the kind of idealistic radicalism which Professor Lewis finds so appealing was the shoe plant....[I]t was distinguished in its execution chiefly by its lack of success, by reason not of incompetent management, but of the fundamental unfeasibility of the basic idea. Puerto Rico contains roughly two million people, or approximately four million feet. At a rate of only one shoe per foot per year, this population should be a more than adequate outlet for one shoe factory. But when this group is broken down into male and female, and within each category into the different age groups, each of which demands a different type of shoe, and when allowance is made further for those who will go shoeless at whatever cost, and those who will continue to buy imported shoes at whatever cost, the number of feet remaining, on which any given type of shoe will be placed, is substantially smaller. Then there is the problem of style, for a point which humanitarians like Lewis tend to forget is that even the poor sometimes have tastes of their own....[I]t is evident that what is needed to serve this market for four million shoes, is not one large shoe factory, but a hundred small shoe factories; and when the advantages of mass production are thus eliminated, the possibility of competing in price with the United States exporters is also eliminated" (Ross 1957)).

${ }^{30}$ The public enterprises receiving the greatest support were the Land Authority (in charge of nationalizing large farms and then later operating them), the Puerto Rican Industrial Development Co., and the Puerto Rican Development Bank (see Perloff (1950), Table 96, p. 380).
} 
How did the government fund the huge increase in contributions to public enterprises? You can imagine it might be hard to find mainland investors willing to fund the building of a state-owned economy. Fortunately (or maybe unfortunately), the government received an explosion in funds from the U.S. Internal Revenue Service during the war years. This was mainly from an explosion in rum taxes returned to the island. ${ }^{31}$ In 1941, this "rum" revenue was roughly $\$ 4$ million. In 1944 this revenue grew to roughly $\$ 64$ million, accounting for 61 percent of total government revenues. In 1945, the revenue fell to $\$ 37$ million, but still accounted for 47 percent of total government revenues. After the war, the rum tax declined dramatically (see Perloff (1950), Table 98, p. 383). So, the government was flush with cash in the war years and spent much of it on this program (and the one to nationalize farms).

The second reason the program was a major setback regards the signal it sent to mainland investors. Here was a government attempting to create a state-owned industrial sector. At the same time, it was nationalizing large sugarcane farms. And there was more: it was declaring the sugar factories, which sold their product to the mainland, a public utility, subjecting them to rate of return regulation and operational oversight. The signal, of course, was that investing in Puerto Rico, though part of the U.S. judicial system, came with some risk. And if one was to invest, the type of investment would likely be calibrated toward capital that was easily moveable. The setback this caused is, of course, hard to measure but must have been significant.

Why was this policy pursued? The governor of Puerto Rico in the early 1940s was Rex Tugwell, the last U.S.-appointed governor. Tugwell was a veteran of Roosevelt's New Deal team and a big supporter of the policy. There was great support from local politicians as well. For example, in order to start the program, the local legislature had to pass new laws to make it legal.

\footnotetext{
${ }^{31}$ When Puerto Rican rum was sold in the United States, all excise taxes on the rum were returned to Puerto Rico. Later this regulation was extended to rum sold in the United States that was produced anywhere in the world (see, e.g., Maguire and Teefy (2010)).
} 


\subsection{Restrictions on Tourism}

After dumping the program to create a state-owned industrial sector, the local government pursued an industrialization policy that sought, among other things, to attract mainland capital. One part of this program was to attract capital to the tourism industry. But as this section makes clear, the policies put in place are better described as policies to restrict tourism. The title of this section had originally been labeled "Promotion of Tourism," as the government reports had been titled, but the title began to make little sense to us.

As we said, mainland capital was sought for hotels and the like. From the start, however, the government put significant restraints on the growth of the industry. It did not want the industry to exceed 5 to 10 percent of GDP (Merrill, 2001, p. 190).

As for restraints, first, the government restricted the amount of new investment in hotels and the like. Second, there was the requirement that any tourism project be a public-private partnership.

While these were direct restraints, there were also indirect ones. A local Puerto Rican law was passed in the early 1950s which required that hotel workers be paid double-time on their day off (they worked six days, with one day off). ${ }^{32}$ Given that hotel workers were subject to minimum wages set by the Puerto Rican insular minimum wage board, this double-pay law may well have had real consequences, though we have not studied it enough to say so with great confidence. Another indirect restraint, though not a formal policy, was that many Puerto Ricans frowned on tourists from the mainland. ${ }^{33}$

How has Puerto Rican tourism fared? Only recently has a theoretically sound method been constructed to calculate tourism's share of GDP (i.e., the tourism satellite accounts). We know of estimates from 1988 to 2011 (which are available on the World Travel and Tourism Council webpage). ${ }^{34}$

\footnotetext{
${ }^{32}$ See Government of Puerto Rico, Annual Report of the Secretary of Labor, 1954-55, p. 28, for a discussion of this law.

${ }^{33}$ Mings (1968) begins his paper on Puerto Rican tourism with quotes, from a wide swath of the population, despairing (or at least frowning on) the prospects of increased tourism.

${ }^{34}$ The data cited in this section, unless otherwise noted, are from the website of the World Travel and
} 
In 1988, the Puerto Rican tourism industry accounted for 2.3 percent of GDP. This share obviously falls significantly short of the government's range, which was 5 to 10 percent of GDP. This was lower than even the mainland U.S. share of 2.6 percent. It was far below the (unweighted) world average of 5.1 percent and even below the (weighted) world average of 2.7 percent. The Puerto Rican restraints on tourism were very effective.

There is a view that countries should be wary of using tourism as part of a development strategy. Some even speak of a "tourism trap." On this view, Puerto Rico has done well to limit tourism. This view, we guess, sees tourism as generating low-paying jobs, like dishwashers, busboys, and the like. But tourism generates lots of professional employment as well. The government of Hawaii (2001), for example, presents a breakdown of tourism spending by category. As an example, spending by tourists on fashion (14.5 percent of total) exceeds that spent on food at restaurants (12.6 percent of total) (Table 2, p. 11). A "trapper" might see poorly paid retail workers at these fashion stores, but there are also small shop owners, designers, artists, and other professionals to consider. In our mind, it's not clear on a priori grounds that tourism is a trap.

If one actually looks at the world, one finds many countries and regions that have employed their comparative advantage as a tourist destination as part of a successful development program. This is true for regions and states in the United States. Hawaii and Florida are two cases. While the U.S. government does not produce tourism satellite accounts for states, researchers have done so for Hawaii. They estimated Hawaii's tourism share, in 2010, to be 16.4 percent of GDP (see Tian, Mak, and Leung, 2011, p. 15). For Puerto Rico, in 2010, the share of tourism was 2.1 percent of GDP (less than its share of 2.3 in 1988). Hawaii's share, then, is over seven times as large. Needless to say, Hawaii has done very well compared to Puerto Rico in terms of economic development.

Unfortunately, at this point, there are no estimates of tourism's share of GDP in Florida. Satellite accounts have not been constructed for the state. It is possible to make some Tourism Council, www.wttc.org. 
back-of-the-envelope calculations for Florida.

One simple way to compare the economic role of tourism in different locations is to compute the ratio of tourist arrivals to local population in a given year. Tourist arrivals are widely available. In Hawaii, in 2010, this ratio was 5.1. ${ }^{35}$ In Puerto Rico, in 2010, this ratio was 1.0. ${ }^{36}$ Recall the ratio of tourism share of GDP in Hawaii to Puerto Rico is roughly 7, which is fairly close to the ratio of tourist arrivals (to population) of 5 . Tourist stays are likely longer in Hawaii.

In Florida, in 2010, this ratio was 4.4. ${ }^{37}$ So, its ratio is much closer to Hawaii's than Puerto Rico's. It's reasonable to assume that when satellite accounts are developed for Florida, it will show a much bigger tourism share of GDP than in Puerto Rico.

Looking beyond U.S. states, one sees that the promotion of tourism has been a part of many successful development programs. Here we give just a few examples from around the world.

In the Caribbean, the Bahamas is a country that has embraced tourism. Its tourism share in 1988 was 21.0 percent. The Bahamas has also had a strong economic development record. Its income per capita was roughly twice that of Puerto Rico in $1988 .{ }^{38}$

If one looks at Southeast Asia, one finds that the tourism share of GDP in Singapore in 1988 was 6.7 percent, nearly three times larger than Puerto Rico's 2.3 percent share. Malaysia's share was 6.0 percent.

In Europe, the shares in Greece, Portugal, and Spain were 6.0, 5.3, and 6.3 percent, respectively, in 1988. In France and Italy, the shares were 3.8 and 3.5 percent, respectively, in 1988.

\footnotetext{
${ }^{35}$ Arrivals: 6.92 million (http://www.hawaiitourismauthority.org/research/reports/historical-visitorstatistics/). Population: 1.36 million (U.S. Census).

${ }^{36}$ Arrivals: 3.68 million (http://data.worldbank.org/indicator/ST.INT.ARVL). Population: 3.73 million (U.S. Census).

${ }^{37}$ Arrivals: 82.3 million (http://media.visitflorida.org/research.php). Population: 18.8 million million (U.S. Census).

${ }^{38}$ The Bahamian dollar trades on a one-for-one basis with the U.S. dollar (as part of Bahama's policy). We have compared the incomes in current dollars. The GNI per capita in the Bahamas, relative to Puerto Rico, was about 2 in 1988. Over the years 1960-2007, the average was 1.66. The data come from the World Bank's WDI database.
} 
In summary, the tourism policies of the government have led to a sector that is extremely small by any measure. That is why we chose the subtitle "Restrictions on Tourism" rather than "Promotion of Tourism" for this section. In any case, the policies must be considered a major setback to economic development on the island.

Why did the government pursue such a policy (which ultimately meant that tourism was tiny)? Again, it made good politics. Many Puerto Ricans felt that tourism was a manifestation of colonialism that would contaminate Puerto Rican culture. Luís Muñoz Marín, who was a leader of the Popular Democratic Party (PPD) and a governor for many decades, used this as part of the PPD platform. "Munoz recognized in anti-tourism an issue that could carry dividends at the ballot box. In the 1940 legislative elections, he echoed others in denouncing [Beeckman] Winthrop's tourism initiatives" (Merrill 2001, p. 189). Winthrop was a U.S.-appointed governor in the 1930s who had promoted tourism on the island. Munoz even wanted tourist facilities to be physically separated from the rest of Puerto Rico by parks (Mings 1968).

\subsection{Tax Haven and Other Benefits for New Investment}

While the Puerto Rican government was pursuing policies that led mainland capital to flee the sugar manufacturing industry and was putting significant restrictions on investment of

mainland capital in the tourist industry, it was creating a different set of policies that sought to attract mainland capital. These policies included constructing factories on the island and offering mainland companies generous leasing terms to fill the factories. They also involved creating a tax haven for mainland firms.

Puerto Rican citizens and corporations do not pay federal income taxes (no taxation without representation). In the late 1940s, Puerto Rico waved all local taxes on mainland corporations that built new plants on the island (income, property, and so on). There were restrictions. The plant would have to be in a new industry. And the exemption was to run out after 10 years. 
Economists are typically skeptical that such tax holidays benefit the local areas giving the breaks. On the positive side, the goal was that plants would stay after the 10 years. On the negative side, taxes must be paid (by someone) to provide the services required by the new tax-exempt businesses.

Figuring out whether a tax holiday is (or was) in the best interests of the local area is obviously a difficult exercise. What would the economy have looked like without the tax haven? We know of no comprehensive study (calculating costs and benefits) to gauge whether the policy benefited Puerto Rico. One study, which examined one aspect of the issue, is disquieting. Bond (1981) contrasted the exit rates in Puerto Rico with those in the mainland (for a large manufacturing industry in Puerto Rico) and concluded that many "tax-exempt" factories were indeed closing after their local tax exemption status expired.

There are other studies of the Puerto Rico tax haven, but these are done from the perspective of the U.S. taxpayer. We briefly discuss these, since they do provide some indirect evidence about how the program has influenced Puerto Rico. Given the zero tax rate in Puerto Rico, mainland firms had a great incentive, using accounting gimmicks, to "shift" profits to Puerto Rico. A firm would say production had occurred in a Puerto Rican subsidiary when in fact it had not. If this were the case, then U.S. taxpayers would be losing as mainland companies "cheated" on taxes. This practice of income shifting was extensive (see, e.g., Grubert and Slemrod (1998) and Pelzman (2002)). ${ }^{39}$

What does this have to say, indirectly, about how the tax-haven program influenced Puerto Rico? It suggests a lack of commitment by mainland corporations to the island.

\footnotetext{
${ }^{39}$ This use of tax havens as a way to shift profits is very widespread and by no means isolated to Puerto Rico. Lipsey (2007) argues that foreign affiliates in tax havens produce little output relative to their (reported) large foreign direct investment (FDI) stocks due to profit shifting. Reported FDI stocks are very large relative to factors that are closely related to production, such as physical capital stock or employment. For example, U.S. affiliates in Caribbean tax havens have 10 times more assets per employee than affiliates in Europe. In 1999, tax havens accounted for 30 percent of affiliates' profits despite accounting for less than 4 percent of employment.
} 


\subsection{Summary of Industrial Policy during the 1940s and 1950s}

In the 1940s and 1950s, Puerto Rico pursued a number of economic policies that were significant deterrents to its economic development. These policies included (1) those that killed the sugar industry; (2) a short-lived policy to create a state-run industrial sector; (3) a long-lived policy that meant tourism was to be a very small part of the economy; and (4) a long-lived policy that gave a tax haven to mainland corporations (who primarily used Puerto Rico as a haven to shift profits). This is an impressive list of policies in terms of the impact they would have on economic development. These policies may have been the source of Puerto Rico's overall poor performance starting in the late 1930s.

Davis and Rivera-Batiz (2006) provide an extensive discussion of more recent industrial policy in Puerto Rico over the last 40 years or so. A major theme is that local economic policy has led to a climate that is not conducive to private sector business growth. They conclude that these policies are responsible, in large part, for very low employment rates on the island. They do an in-depth study of the construction industry, documenting the extensive regulations that must be followed in that industry. These regulations lead to high construction costs and are likely a big part of the reason for high housing costs on the island (see below).

\section{Conclusion}

In this paper we have discussed many of the policies directed toward the Puerto Rican sugar industry in the 1930s and 1940s. We have presented significant evidence that these policies were responsible for the industry's demise.

We have described many other policies undertaken by the Puerto Rican government at this time. They were a significant obstacle to economic development. The policies included those that killed the sugar industry, a short-lived policy to create a state-run industrial sector, a long-lived policy that meant tourism was to be a very small part of the economy, 
and a long-lived policy that gave a tax haven to corporations (who primarily seem to have used Puerto Rico as a haven to shift profits). This is an impressive list of policies in terms of the impact they would have on economic development. These policies may have been the source of Puerto Rico's overall poor performance starting in the late 1930s.

One policy that was discussed in Puerto Rico, but never pursued, was a proposal to greatly reduce trading with the United States and replace it with trade with other Caribbean countries. A professor at the University of Puerto Rico, one Gordon Lewis, was such a proponent (see Lewis (1955)). David Ross (1957, p. 100), who at the time worked for the Economic Development Administration of Puerto Rico, wrote a reply to Lewis, stating,

We may have, in short, nothing to lose but money by giving up our trading connections with the U.S.--but we need the money. If Puerto Ricans should, after full consideration of the alternatives, opt for poverty and cultural purity instead of prosperity and mainland ties, no one should deny their right to make such a choice; but it is hardly Professor Lewis's place to make it for them.

We agree with Ross. In a democratic society, it is the right of the people to choose their future. The Puerto Rican people made choices, through their representatives, to pursue the policies toward the sugar industry discussed above (and the other policies discussed).

It is, of course, sometimes difficult to predict the consequences of policies. In fact, even after the policies have been implemented, it may be very hard to quantify the consequences. The purpose of this paper has been to show the consequences of the policies toward sugar. As Puerto Ricans look to their future, including their economic future, it's important that they have a fuller understanding of how previous policies worked.

\section{Appendix: Puerto Rico and the U.S. South, 1929-1985}

In this Appendix, we evaluate the economic performance of the Puerto Rican economy by comparing its performance to U.S. states. In particular, we compare it to those states closest in income to Puerto Rico, namely, the southern states. Given that Puerto Rico is 
integrated into the U.S. economy, the southern states seem a reasonable comparison group. Given the strong convergence forces that have been documented among U.S. states (see, e.g., Barro and Sala-i-Martin (1992)), one expects that Puerto Rico would be converging to these states. That convergence was happening before World War II, but has stopped since then.

We compare personal income per capita. Personal income is the sum of labor compensation (excluding employer and employee contributions to social insurance), dividends, interest, rent, and transfers received by residents. We choose this measure because of its availability over a long time period and because it does not include profits earned by mainland-held companies operating in Puerto Rico. Mainland companies constitute a significant portion of Puerto Rico's economy, so by choosing a measure that omits their profits, we gain a more accurate summary measure of an average resident's well-being.

For the period 1929-1985, we compare personal income per capita in Puerto Rico with that in Mississippi, Alabama, and Arkansas, the three states with the lowest per capita incomes in 1929. The data for Puerto Rico are mainly from Puerto Rico's official national accounts, though we use estimates prepared by independent researchers working in conjunction with the insular government for the years 1929-46. (See "Sources" below.) Figures on state personal income come from the BEA's Survey of Current Business. We compare the income in dollars, with no adjustment for price differences. We discuss this issue, and many others, after we have presented the basic facts.

Figures A1-A3 plot Puerto Rico's per capita personal income relative to that of Mississippi, Alabama, and Arkansas. Let's first discuss Figure A1, the comparison with Mississippi. In 1929, Puerto Rico's income per capita was 41 percent of Mississippi's. During the Great Depression, Puerto Rico's relative income soared. We explain why shortly. But even if we compare Puerto Rico's relative income in 1929 to a year when the Great Depression was mostly over and World War II had not started, such as 1938, 1939, or 1940, we see that there was strong convergence of Puerto Rico's income to Mississippi's.

With the war, Puerto Rico's relative income fell dramatically. German submarines were 
creating havoc with, and sinking, Caribbean ships, and this was likely a big reason for Puerto Rico's drop in income. But there was more to it, it seems. The vast majority of the sinkings were during 1942. And once the war ended, Puerto Rico's relative income was not increasing relative to Mississippi's. It was not until the 1960s that some catch-up began, though this was short-lived.

Next consider Figures A2 and A3, where Puerto Rico is compared to Alabama and Arkansas. They tell pretty much the same story as A1.

We now turn to some remarks on the income comparisons.

\section{Remark 1. Puerto Rico Compared to Overall United States}

Others have contrasted Puerto Rico with the total U.S. economy. For example, Bosworth and Collins (2006) compare Puerto Rico's GNP per capita to that in the United States in the post-World War II period. In their Table 2.1, they show that this ratio (Puerto Rico relative to the United States) in the years 1950, 1960, 1970, 1980, and 1990 was 22.6, 29.1, 36.9, 35.0, and 31.6. Hence, there was a modest catch-up over 1950-70, about 14 percentage points. But this is clearly a small amount. Given these findings by Bosworth and Collins (2006), it should not be surprising that we find that Puerto Rico was not converging to the southern U.S. states in the post-World War II period.

But this leads to critical questions: Was Puerto Rico converging to the southern states before World War II? And if so, when had the convergence stopped? From 1929 until the late 1930s, Puerto Rico was converging to these states. That stopped in the late 1930s.

\section{Remark 2. Cost of Living Adjustments}

Our comparisons are of nominal personal income. Attempting to adjust these incomes for cost of living differences is a difficult task. We surveyed the available data and, unfortunately, there is no off-the-shelf way to make cost of living adjustments (if we require the data to be at least of some minimum quality). However, there are cost of living comparisons available, though for only parts of budgets or for only a few years. These data indicate that the cost of living in Puerto Rico is higher than in the southern states. We think the picture given by the 
nominal income data is, if anything, too rosy a picture regarding Puerto Rico's performance.

Penn World Tables

The Penn World Tables (PWT) does provide a PPP series for Puerto Rico. However, the data quality is low. No price benchmark has been done for Puerto Rico. Rather, the PWT calculated a PPP value for Puerto Rico in 1996 from two pieces of information.

One is the U.S. government program to calculate the cost of living for a U.S. government worker living in U.S. possessions (the Cost-of-Living Allowances [COLA] in Nonforeign Areas program). A cost of living is computed for the worker in Puerto Rico and then compared to the cost of living in Washington DC. The second piece of information is the nominal wages in Puerto Rico.

As for the 1996 value of Puerto Rico's PPP, the COLA program found Puerto Rico to be a more expensive place to live than Washington DC. Despite this, the PWT places Puerto Rico's cost of living below that of the United States. This finding is driven by the assumption that Puerto Rico's low nominal wages reflect a low cost of living (rather than, say, very low productivity producing nontraded goods).

With this 1996 value, then, a Puerto Rico PPP series is calculated by extrapolation using price indices. ${ }^{40}$ We have chosen not to use these data because the quality is too low.

\section{Other Price Programs}

The COLA program mentioned above has been conducted five times between 1950 and 1976. It has consistently found Puerto Rico to be a more expensive place to live than Washington DC (see, e.g., Federal Register 15, March 18, 1950, p. 1537). While one might think of using these data, they obviously have many problems, not least that the methodology has changed over time.

Federal programs have compared the cost of food between Puerto Rico and U.S. states. The federal government collected data on the cost of a food budget to adjust food stamp benefits. Food prices in Puerto Rico and Washington DC were similar and were more than

\footnotetext{
${ }^{40}$ Johnson, Larson, Papageorgiou, and Subramanian (2009) have shown that when this method is used, measures of real growth are very sensitive to the benchmark year used.
} 
in the South.

Some housing prices have also been compared. Examining Federal Housing Administration data, Manheim (1972) finds that housing costs were 25 percent higher than on the mainland. This number understates the cost in Puerto Rico, since those lots are smaller than on the mainland. Compared to the South, costs are even higher. The median price of existing houses whose mortgages were insured by the FHA were almost 40 percent higher in San Juan than Mississippi in the late 1960s.

This finding of high housing costs might seem counterintuitive. After all, Puerto Rico is a warm climate, and this should reduce construction costs. Two forces in Puerto Rico lead to the higher prices.

First, Puerto Rico has a greater urban population than most southern states. In 1950, the urban share of the population in Puerto Rico was 40.5 percent. In Mississippi, Arkansas, and Alabama, the urban shares were 27.9, 33.0, and 43.8. In 1970, the urban share of the population in Puerto Rico was 58.1 percent. In Mississippi, Arkansas, and Alabama, the urban shares were 44.5, 50.0, and 58.6. So, Puerto Rico's share was about 12 percentage points higher than Mississippi's over the 20-year period. It was about 7 percentage points higher than in Arkansas. Alabama had a larger share in 1950, but the difference was tiny in 1970.

Second - and this brings us to policy again-Davis and Rivera-Batiz (2006) document the complex regulations that must be negotiated in Puerto Rico in the construction sector. These regulations may well be the largest reason for housing price differences.

\section{Remark 3. Puerto Rico's Strength during Depression}

Puerto Rico's income (relative to the South) soared during the Depression. In particular, its drop in income was mild relative to the drops experienced in the southern states. At the bottom of the Depression in 1933, income in Puerto Rico was 76 percent of its 1929 level, compared to 46 percent in Mississippi and 55 percent in the United States as a whole. Some of the difference may be due to differences in the inflation (or deflation) rate between the 
mainland and Puerto Rico during the Depression, but we do not have price deflators for Puerto Rico during that period.

However, we think there are two major reasons for Puerto Rico's better performance. First, the sugar industry did very well during the Depression. Second, the agricultural industries in the South did very poorly.

As for the sugar industry, and again looking at Figure 1, one sees that between 1929 and 1934 (when the cartel started), production (in tons) grew by well over 50 percent.

Moreover, during this period, the price of sugar was strong. The New York price of raw sugar at the port was 3.76 (cents per pound) in 1929; in 1936, it was 3.59, a drop of 5 percent. Over the same period, the world price of sugar (a London price) went from 1.77 in 1929 to 0.88 in 1936, a drop of 50 percent.

Given that production (in tons) was strongly growing and that the nominal price of sugar was not falling much, the gross output (or revenue) of the sugar industry surged during the Depression. Gross output, relative to its level in 1929, was up nearly 60 percent in some years. Again, this is in current dollars. So, the income (value-added) in the industry was likely up more (as the price of its materials was likely falling a lot).

The South specialized in agriculture (relative to the overall United States). Prices for farm products were extremely weak during the Depression. The index for prices received by farmers in 1933 was 47 percent of its 1929 level (Table 64, p. 113, Sugar Statistics, vol. 1 (revised), Statistical Bulletin 293, 1974). This significant fall in farm prices was a big reason for the South's larger fall in income.

\section{Remark 4. Industry Diversification}

The sugar industry's strength during the Depression leads us to discuss diversification. Here are some things we have not said until now. We think they are obvious but are stating them to avoid confusion. (1) We are not saying that the sugar industry should be a big part of the Puerto Rican economy today. (2) While the sugar industry was responsible for the relatively good performance of Puerto Rico during the Depression, there are good reasons 
to diversify industry. Though the sugar industry did well during the Depression, it might do terribly in other periods. (3) But the answer to diversification is not to kill the industry. True, if the industry is gone, the economy is no longer susceptible to its fluctuations, but it's also poorer. Moreover, the diversification would have emerged in the process of development. While the share of the population working in the sugar industry in Hawaii was roughly the same as in Puerto Rico in the 1930s, the Hawaiian share quickly dropped after World War II. Hawaii mechanized its sugar manufacturing, leading to the large drop in employment.

\section{Remark 5. Disadvantages of Puerto Rico Relative to South}

One disadvantage Puerto Rico suffers relative to the southern states is that it's an island and is somewhat isolated (flying distance to Miami is 1,019 miles, to New York 1,617 miles). But, of course, Hawaii is also an island and is more isolated (flying distance to San Francisco is 2,388, to Los Angeles 2,551 miles), and yet it has done very well.

\section{Remark 6. Removing Transfers to Individuals}

When other researchers have compared personal income per capita across U.S. states, they have deducted the transfers to individuals, namely, "personal current transfer receipts." The logic is to look at earned income. We can deduct such transfers from the Puerto Rican personal income numbers for the years 1940-1985. Before 1940, we do not have a detailed enough breakdown of personal income. In order to present the longest time series possible, we have used the personal income figures (with transfers included) from 1929 to 1985.

During the 1950s and 1960s, if we eliminated transfers, this would reduce Puerto Rico's relative income by 1 to 3 percentage points. In 1975 and thereafter, eliminating transfers would reduce Puerto Rico's relative income by 6 to 7 percentage points.

\section{Remark 7. Underground Economy}

Measurements of personal income will miss income earned in the underground economy. This underground income is likely higher in Puerto Rico than in the southern states, though we have not really studied this issue in great detail yet. To the extent this is true, Puerto Rico's income (measured and underground) relative to the states will be higher than the 
measured income we have presented.

\section{Sources}

The official Puerto Rican national accounts, which report personal income directly, are available for the years 1940 and 1947 to the present. For the period 1929-1939, we use figures

reported in Smith (1943). Using official government reports, Smith computes "Income Paid Out," which is the same income concept as personal income. For the years 1940-46, we use the personal income figures reported in Perloff (1950). Perloff uses revised and updated versions of the national accounts data prepared by Creamer (1947) in cooperation with the Puerto Rico Bureau of the Budget.

\section{References}

Acemoglu, Daron, and James Robinson. 2012. Why Nations Fail: The Origins of Power, Prosperity, and Poverty. New York: Random House.

Adamopoulos, Tasso, and Diego Restuccia. 2011. "The Size Distribution of Farms and International Productivity Differences." Manuscript, University of Toronto.

Association of Sugar Producers of Puerto Rico. 1940. Economic Implications of the 500Acre Law. Washington DC: Association of Sugar Producers of Puerto Rico.

Aten, Bettina. 2006. "Interarea Price Levels: An Experimental Methodology." Monthly Labor Review 129(9), pp. 47-61.

Baer, Werner. 1959. "Puerto Rico: An Evaluation of a Successful Development Program." Quarterly Journal of Economics 73(4), pp. 645-671.

Baretto, Amilcar. 2001. "Statehood, the English Language, and the Politics of Education in Puerto Rico." Polity 34(1), pp. 89-105.

Barro, Robert, J., and Xavier Sala-i-Martin. 1992. "Convergence." Journal of Political Economy 100(2), pp. 223-251. 
Baumol, William J., and Edward N. Wolff. 1996. "Catching Up in the Postwar Period: Puerto Rico as the Fifth 'Tiger'?' World Development 24(5), pp. 869-885.

Bel, Germa. 2009. "The First Privatization Policy in a Democracy: Selling State-Owned Enterprises in 1948-1950 Puerto Rico." Research Institute of Applied Economics Working Paper 2009/15, University of Barcelona.

Bird, Esteban. 1937. "The Sugar Industry in Relation to the Social and Economic System of Puerto Rico." San Juan, Puerto Rico: Bureau of Supplies, Printing, and Transportation.

Bollard, Albert, Peter Klenow, and Gunjan Sharma. Forthcoming. "India's Mysterious Manufacturing Miracle." Review of Economic Dynamics.

Bond, Eric. 1981. "Tax Holidays and Industry Behavior." Review of Economics and Statistics 63(1), pp. 88-95.

Bosworth, Barry, and Susan Collins. 2006. "Economic Growth." In The Economy of Puerto Rico: Restoring Growth, ed. Susan M. Collins, Barry Bosworth, and Miguel A. SotoClass. Washington DC: Brookings Institution Press and Center for the New Economy.

Bridgman, Benjamin, Shi Qi, and James A. Schmitz, Jr. 2009. "The Economic Performance of Cartels: Evidence from the New Deal U.S. Sugar Manufacturing Cartel, 1934-74." Federal Reserve Bank of Minneapolis Staff Report 437.

Burrows, Geof, and Ralph Shlomowitz. 1992. "The Lag in the Mechanization of the Sugarcane Harvest: Some Comparative Perspectives." Agricultural History 66(3), pp. $61-75$.

Coll Cuchi, Cayetano. 1938. La Ruina De La Industria Azucarera. San Juan, Puerto Rico: El Mundo. 
Creamer, Daniel. 1947. "The Net Income of the Puerto Rican Economy, 1940-1944." Social Science Research Center, University of Puerto Rico.

Davis, Steven, and Luis Rivera-Batiz. 2006. "The Climate for Business Development and Employment Growth in Puerto Rico." In The Economy of Puerto Rico: Restoring Growth, ed. Susan M. Collins, Barry Bosworth, and Miguel A. Soto-Class. Washington DC: Brookings Institution Press and Center for the New Economy.

Descartes, S. L. 1943. "Land Reform in Puerto Rico." Journal of Land and Public Utility Economics 19(4), pp. 397-417.

Edel, Matthew. 1963. "Land Reform in Puerto Rico, 1941-1959: Part Two." Caribbean Studies 2(4), pp. 28-50.

Galvin, Miles. 1976. "The Early Development of the Organized Labor Movement in Puerto Rico." Latin American Perspectives 3(3), pp. 17-35.

García-Santana, Manuel, and Josep Pijoan-Mas. 2011. "Small Scale Reservation Laws and the Misallocation of Talent." CEPR Discussion Paper No. 8242.

Garrott, William. 1971. "Labor Productivity on Sugarbeet and Sugarcane Farms in the United States, 1946-69." Sugar Reports 225, pp. 6-26.

Government of Hawaii, Department of Business, Economic Development and Tourism. Feb. 2001. "New Measures of Tourism." Hawaii's Economy, pp. 1-4.

Government of Puerto Rico. Various years. Annual Report of the Secretary of Labor. San Juan, Puerto Rico.

Government of Puerto Rico. 1952-53. State Insurance Fund of Puerto Rico. Seventeenth Annual Report. San Juan, Puerto Rico.

Government of Puerto Rico. 1949-50. Annual Report of the Public Service Commission. San Juan, Puerto Rico. 
Grubert, Harry, and Joel Slemrod. 1998. "The Effect of Taxes on Investment and Income Shifting to Puerto Rico." Review of Economics and Statistics 80(3), pp. 365-373.

Guner, Nezih, Gustavo Ventura, and Xu Yi. 2008. "Macroeconomic Implications of SizeDependent Policies." Review of Economic Dynamics 11(4), pp. 721-744.

Holmes, Thomas J., and Sanghoon Lee. 2012. "Economies of Density versus Natural Advantage: Crop Choice on the Back Forty." Review of Economics and Statistics 94(1), pp. 1-19.

Holmes, Thomas J., and Matthew F. Mitchell. 2008. "A Theory of Factor Allocation and Plant Size." RAND Journal of Economics 39(2), 329-351.

Johnson, Simon, William Larson, Chris Papageorgiou, and Arvind Subramanian. 2009. "Is Newer Better? Penn World Table Revisions and Their Impact on Growth Estimates." NBER Working Paper 15455.

Kennaway, Todd, and E. H. Helmer. 2007. "The Forest Types and Ages Cleared for Land Development in Puerto Rico." GIScience 83 Remote Sensing 44(4), pp. 356-382.

Koenig, Nathan. 1953. A Comprehensive Agricultural Program for Puerto Rico. Washington DC: U.S. Government Printing Office.

Lewis, Gordon K. 1955. "Puerto Rico: A Case-Study of Change in an Underdeveloped Area." Journal of Politics 17(4), pp. 614-650.

Lipsey, Robert E. 2007. "Defining and Measuring the Location of FDI Output." NBER Working Paper 12996.

Lucas, Jr., Robert E. 1978. "On the Size Distribution of Business Firms." Bell Journal of Economics 9(2), pp. 508-523.

Lucas, Jr., Robert E. 1993. "Making a Miracle." Econometrica 61(2), pp. 251-272. 
Maguire, Steven, and Jennifer Teefy. 2010. "The Rum Excise Tax Cover-Over: Legislative History and Current Issues." Congressional Research Service Report R41028.

Manheim, Uriel L. 1972. Puerto Rico Builds: The Island's Housing Market in the 1970s. San Juan, Puerto Rico: Housing Investment Corporation.

Martinez, Alfonso Garcia. 1952-53. "Local Regulation of the Sugar Industry in Puerto Rico." Revista Juridica de U.P.R. 22(1-4), pp. 385-402.

Merrill, Dennis. 2001. "Negotiating Cold War Paradise: U.S. Tourism, Economic Planning, and Cultural Modernity in Twentieth Century Puerto Rico." Diplomatic History 25(2), pp. 179-214.

Mings, Robert. 1968. "Puerto Rico and Tourism: The Struggle for Cultural Autonomy among Developing Nations: The Case of Puerto Rico and Its Tourist Industry." Caribbean Quarterly 14(3), pp. 7-21.

Pelzman, Joseph. 2002. "Imported Capital Dependency as an Economic Development Strategy: The Failure of Distortionary Tax Policies in Puerto Rico." George Washington University Working Paper D0301.

Perloff, Harvey. 1950. Puerto Rico's Economic Future: A Study in Planned Development. Chicago: University of Chicago Press.

Pousada, Alicia. 1999. "The Singularly Strange Story of the English Language in Puerto Rico." Milenio 3, pp. 33-60.

Puerto Rico Policy Commission. 1934. Report of the Puerto Rico Policy Commission: Chardon Report. San Juan: Puerto Rico Policy Commission.

Resnick, Melvin. 1993. "ESL and Language Planning in Puerto Rican Education." TESOL Quarterly 27(2), pp. 259-275. 
Reynolds, Lloyd, and Peter Gregory. 1965. Wages, Productivity and Industrialization in Puerto Rico. Homewood, IL: Richard Irwin.

Ross, David. 1957. "Gordon Lewis on Puerto Rico's Development Program." Journal of Politics 19(1), pp. 86-100.

Scott, Loren C., and Lamar B. Jones. 1974. "The USDA and Wages in the Sugar Crop Industry." Labor Law Journal 25(1), pp. 18-30.

Smith, Dudley. 1943. Puerto Rico's Income: Estimates of Income Realized and Paid Out in Puerto Rico. Washington DC: Association of Sugar Producers of Puerto Rico.

Smith, Dudley. 1966. "Farm and Labor Problems Squeezing Puerto Rican Factories." Sugar y Azucar, November.

Stigler, George J. 1965. "The Economist and the State." American Economic Review $55(1 / 2)$, pp. $1-18$.

Suarez, Nydia. 1998. "The Rise and Decline of Puerto Rico's Sugar Economy." Sugar and Sweetener Situation and Outlook 224, pp. 22-33.

Tian, Eugene, James Mak, and Pingsun Leung. 2011. "The Direct and Indirect Contributions of Tourism to Regional GDP: Hawaii." University of Hawaii Economic Research Organization Working Paper 2011-5.

U.S. Bureau of the Mines. 1947. Minerals Yearbook. Washington DC: U.S. Government Printing Office.

U.S. Department of Agriculture. 1961. "Labor Productivity on Sugar Beet and Sugarcane Farms in the United States." Sugar Reports 115, pp. 19-31.

U.S. Department of Agriculture. 1963. "Sugar Statistics and Related Data." Statistical Bulletin 244(2) (rev.). 
U.S. Department of Labor. 1969. "The Sugarcane Industry in Puerto Rico." Economic Report 89-B, Wage and Hour and Public Contracts Divisions.

U.S. Senate, Committee on Finance. 1973. World Oil Developments and U.S. Oil Import Policies. 93rd Congress, First Session. Washington DC: U.S. Government Printing Office.

U.S. Tariff Commission. 1934. Report to the President of the United States on Sugar. Report No. 73. Washington DC: U.S. Government Printing Office.

Ward, Marianne, and John Devereux. 2012. "The Road Not Taken: Pre-Revolutionary Cuban Living Standards in Comparative Perspective." Journal of Economic History 72(1), pp. 104-132.

Zorrilla, Frank. 1955. "Wage Structure and Minimum Wages." Monthly Labor Review 78, pp. $1368-1372$. 


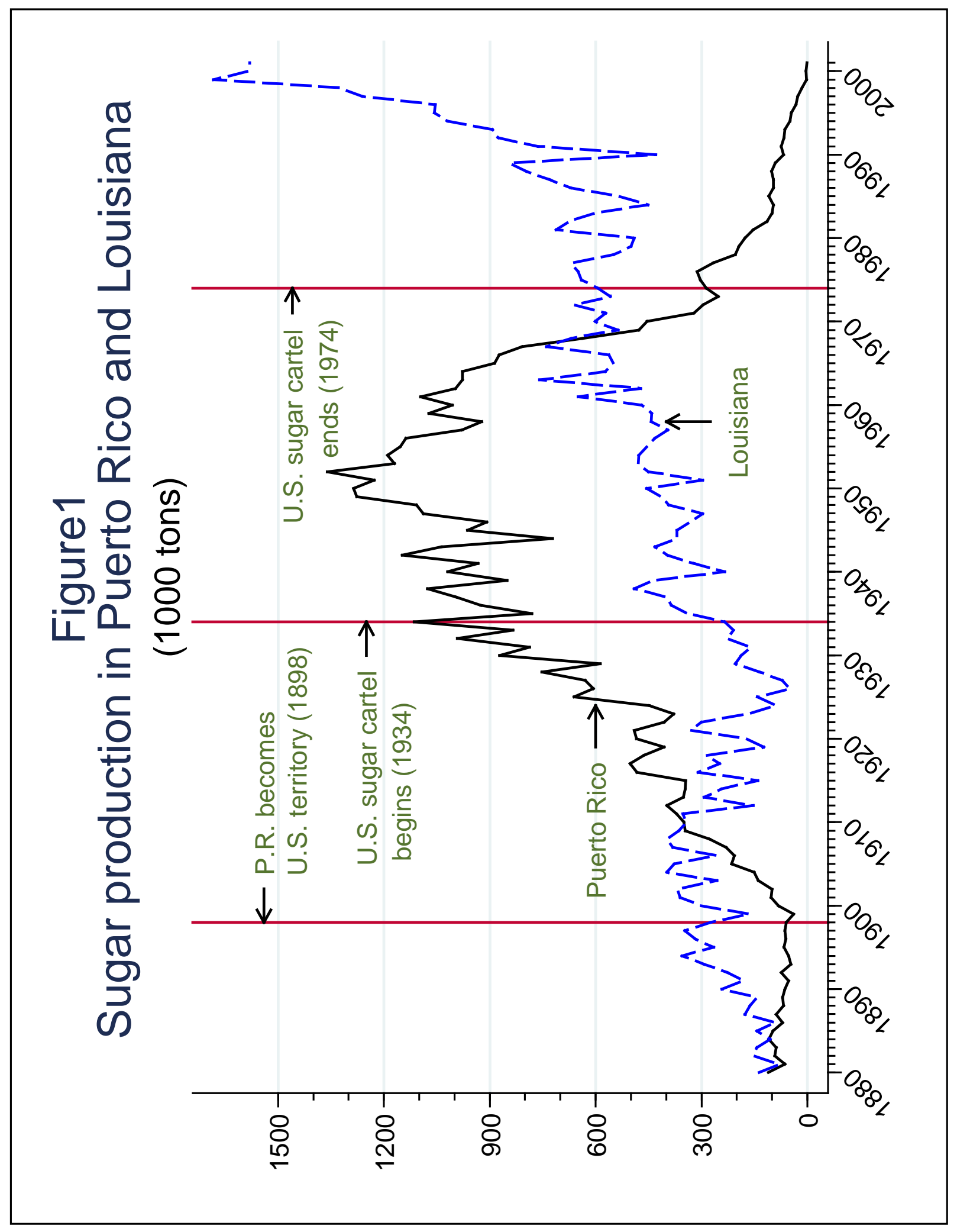




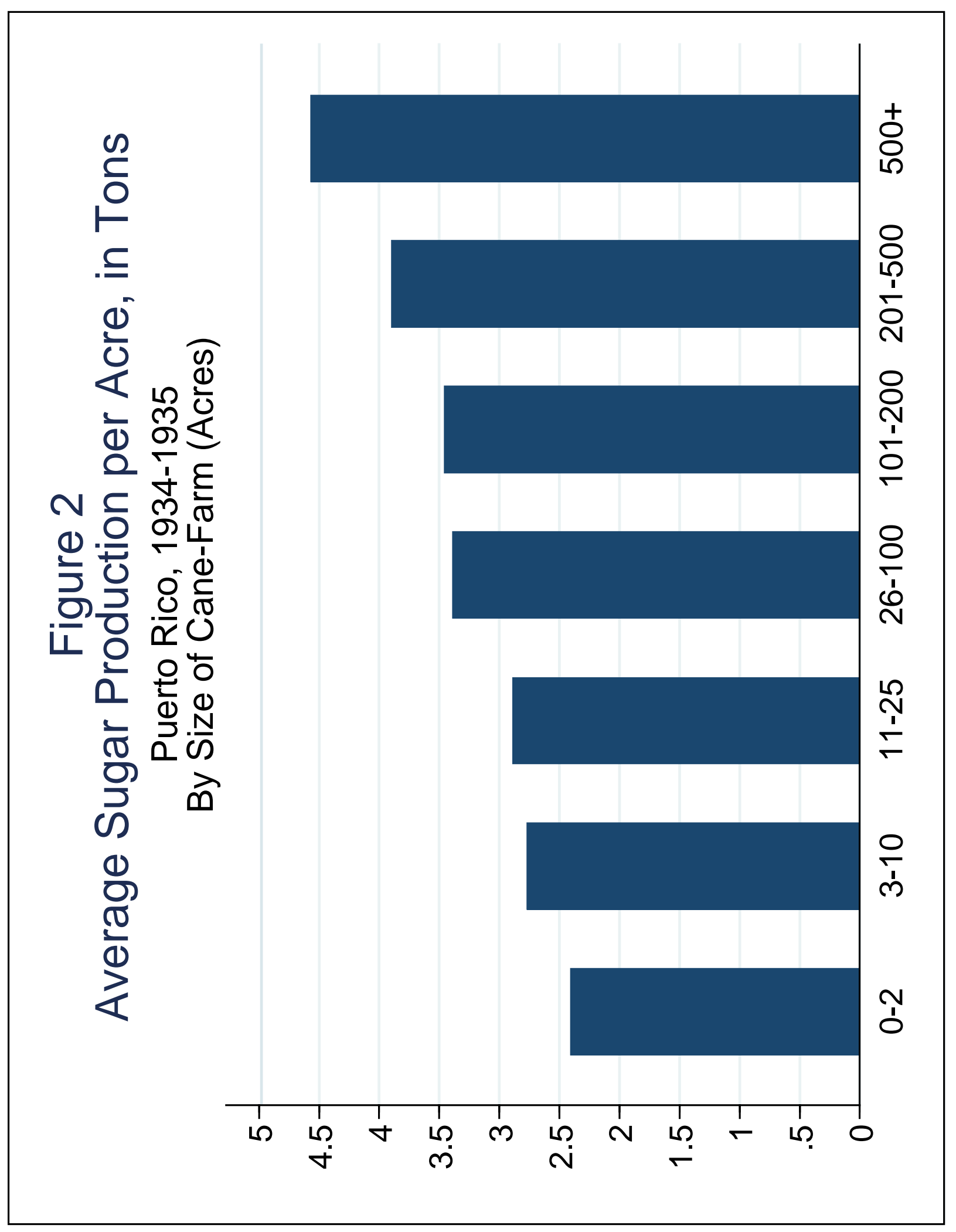




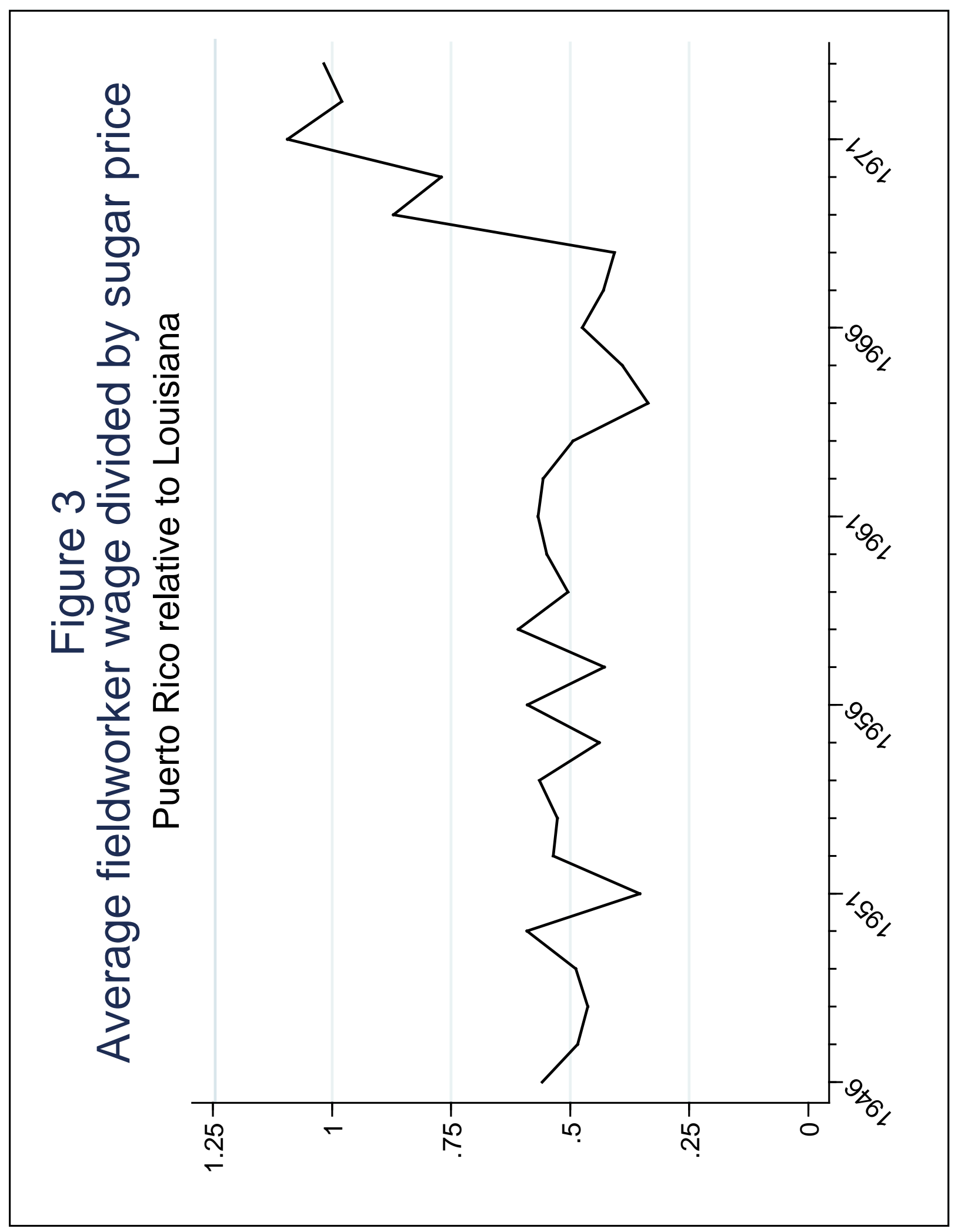




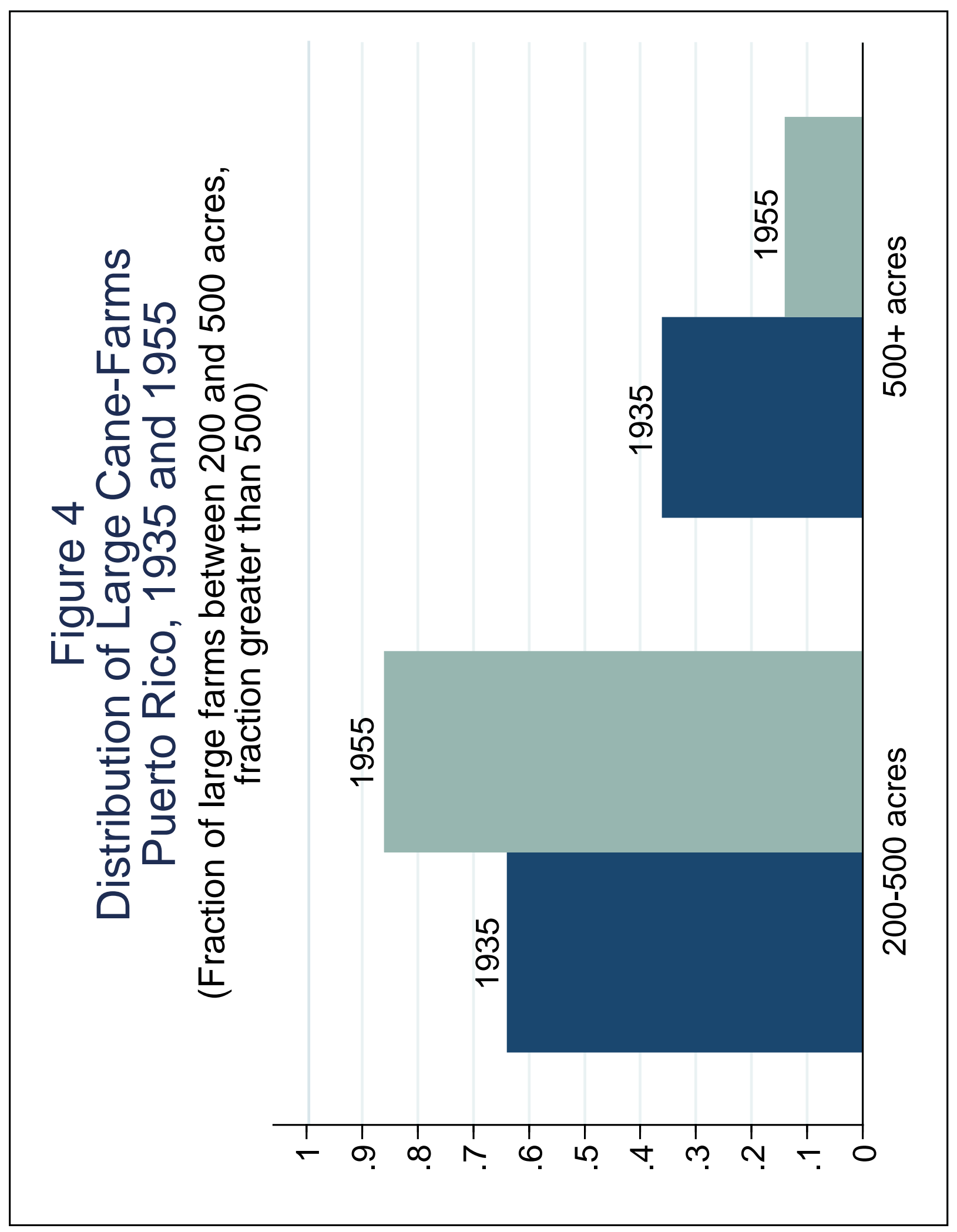




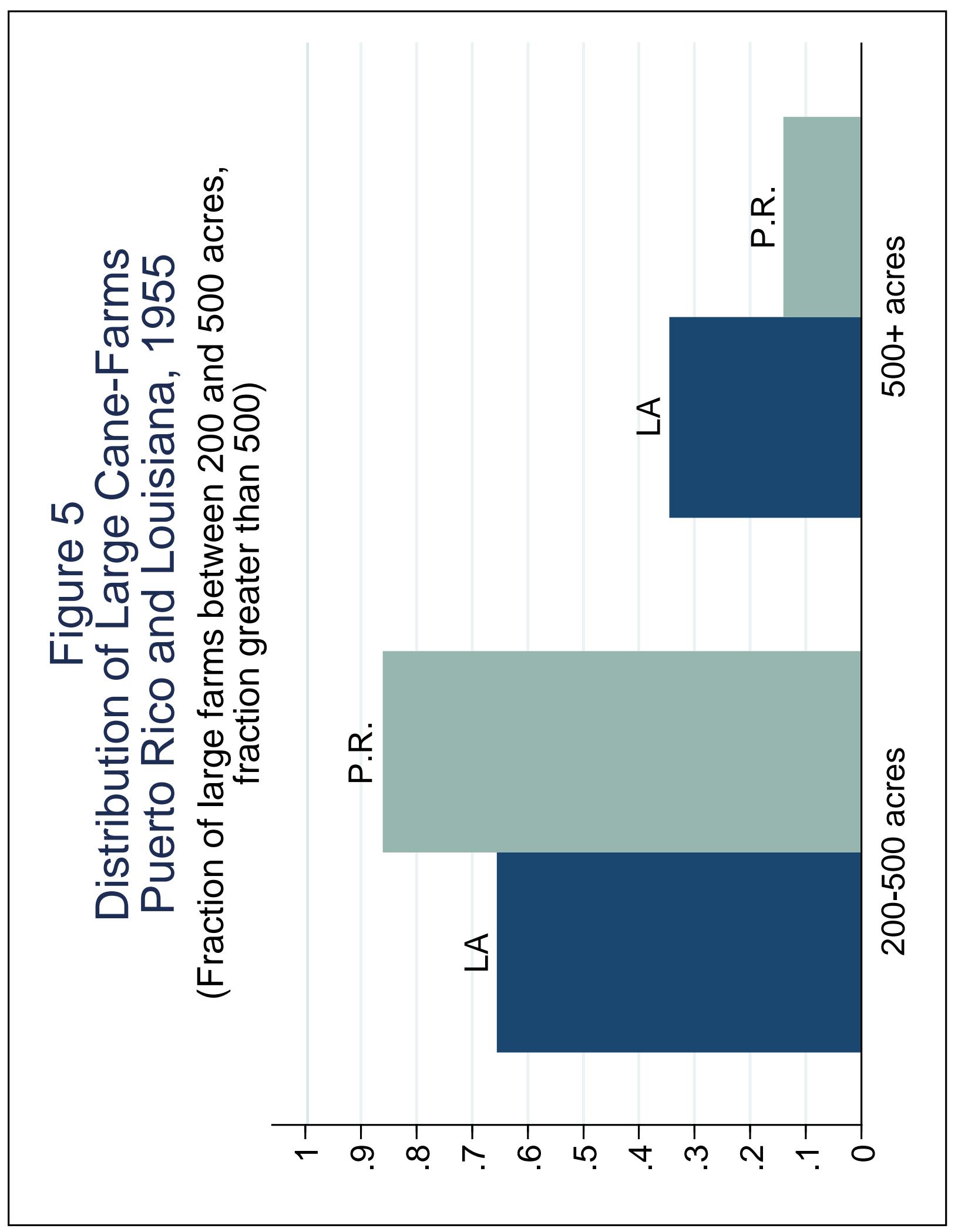




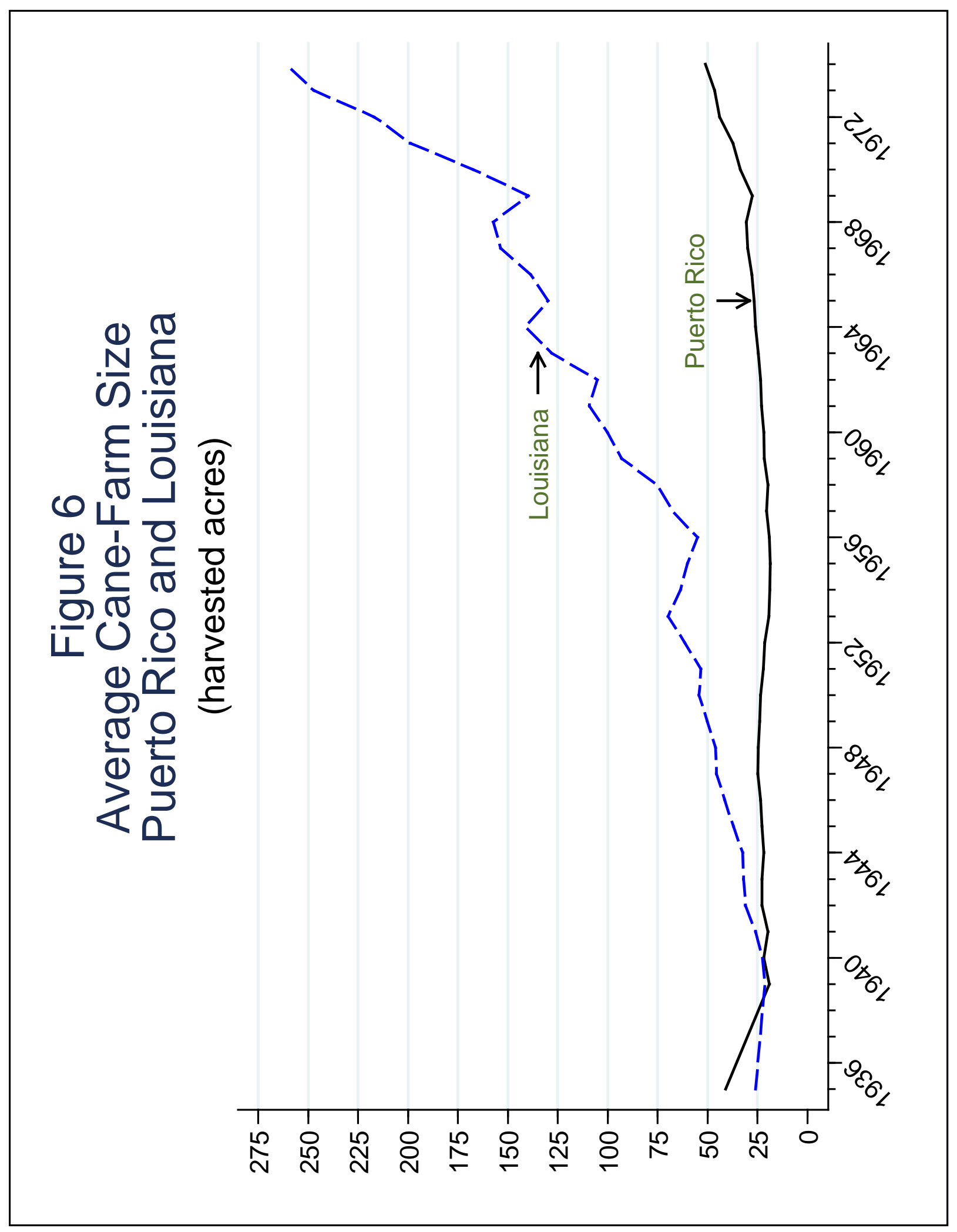




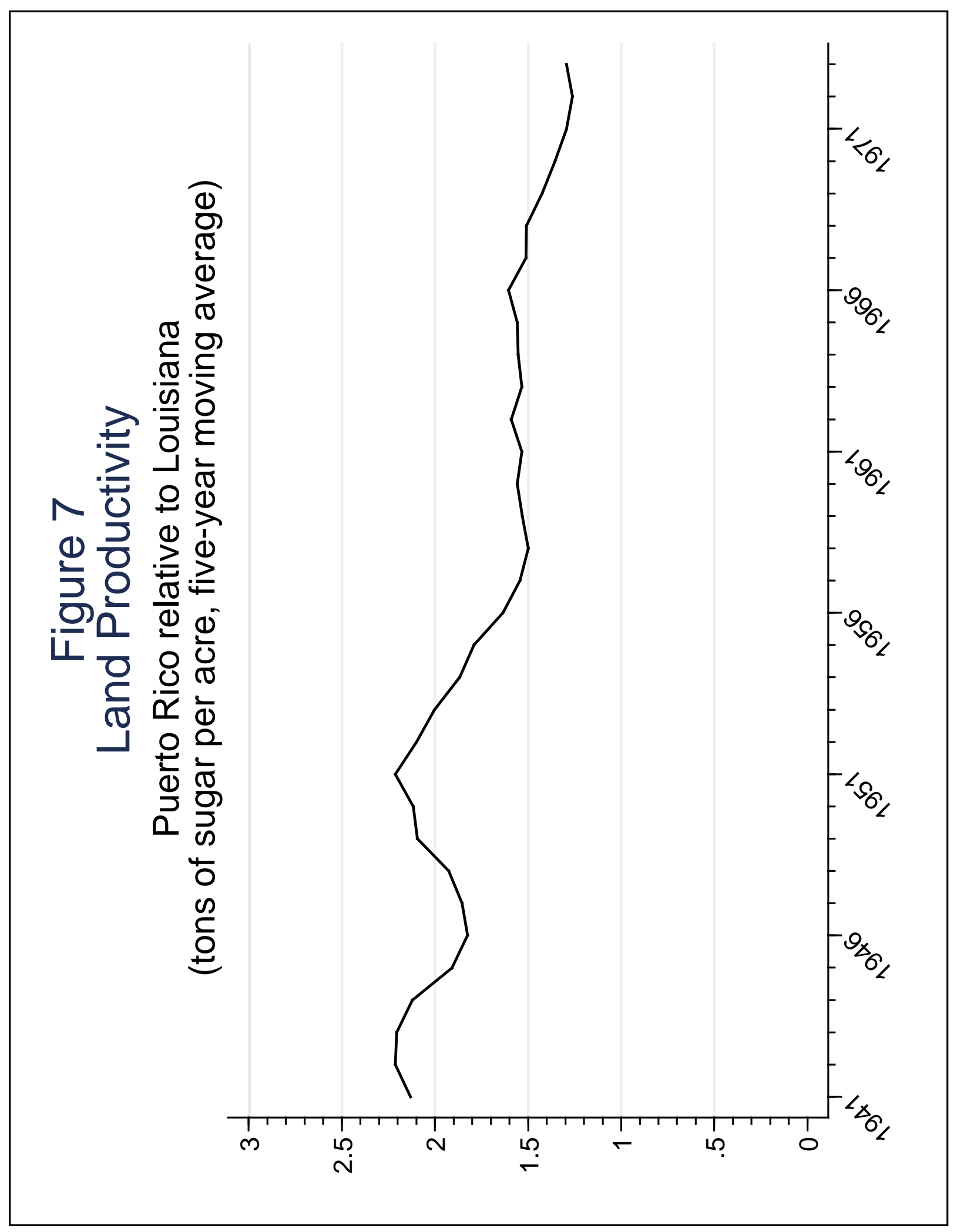




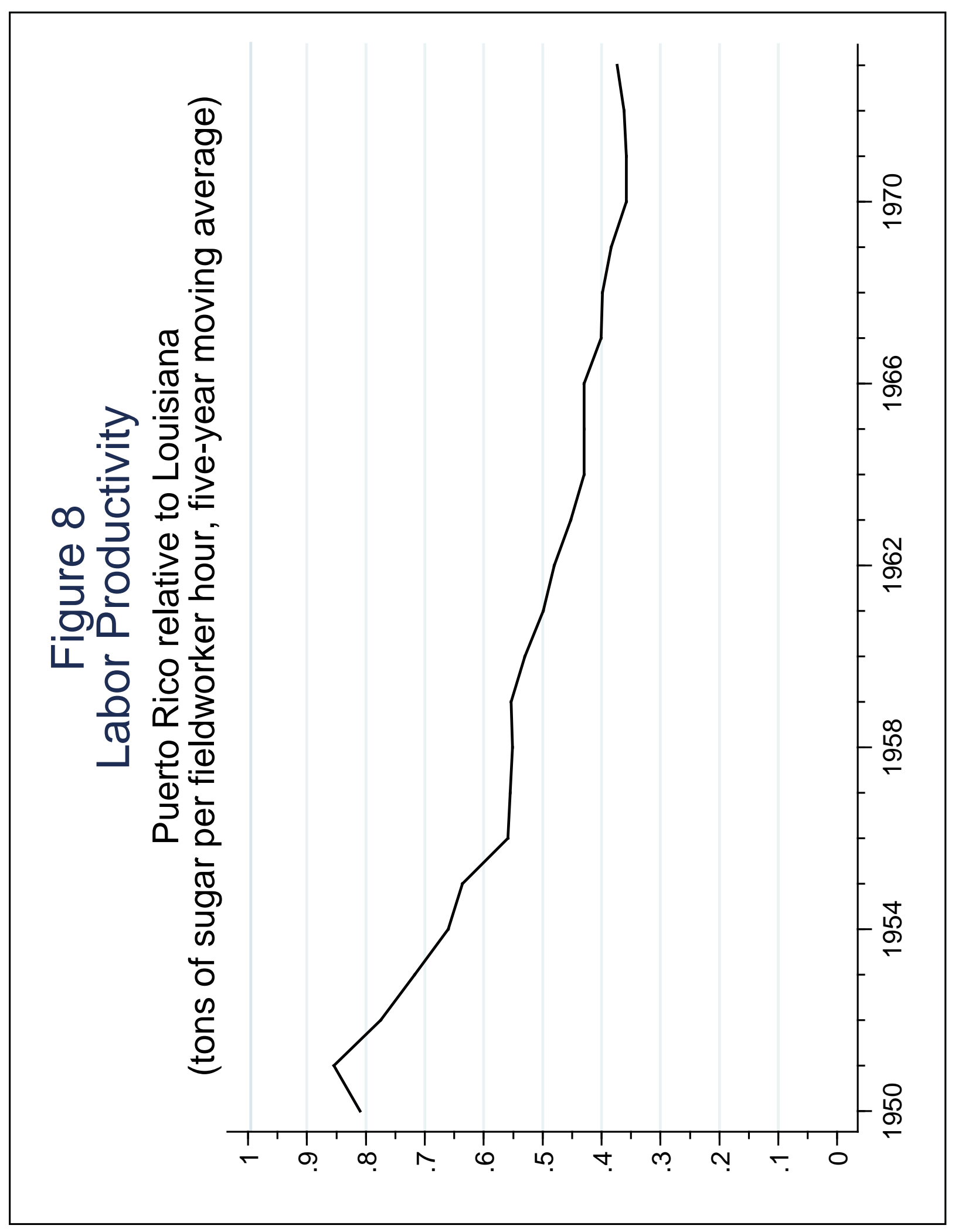




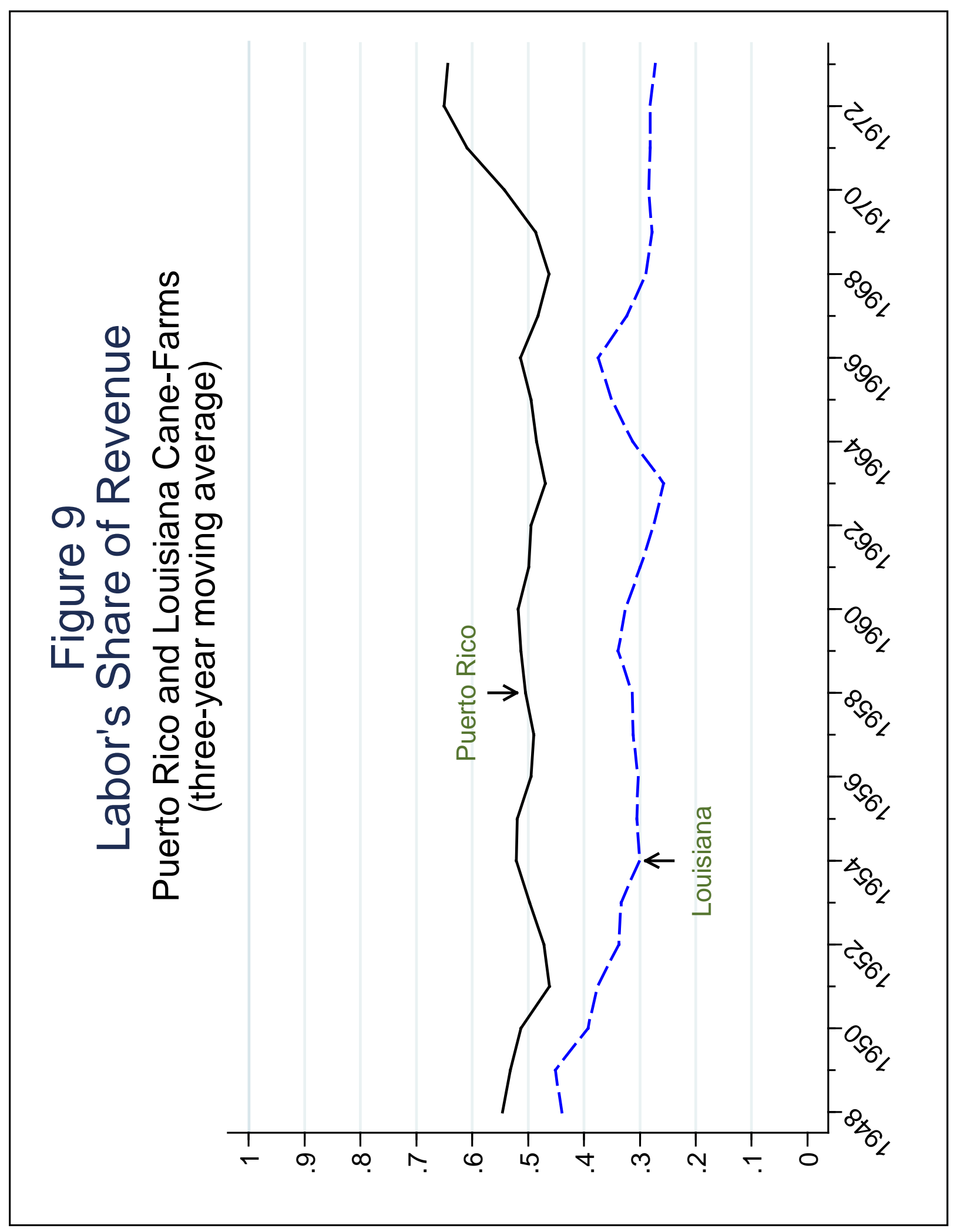




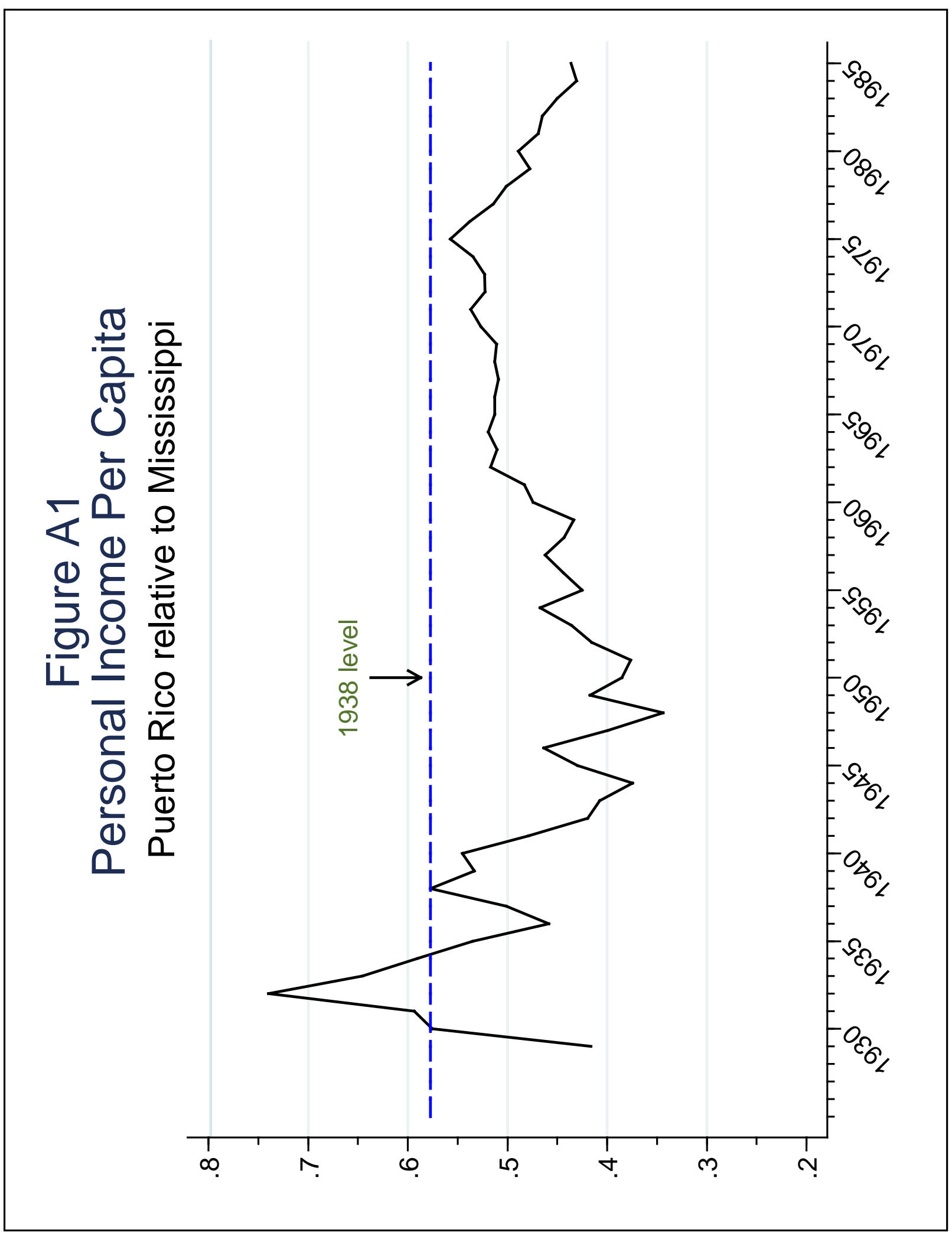




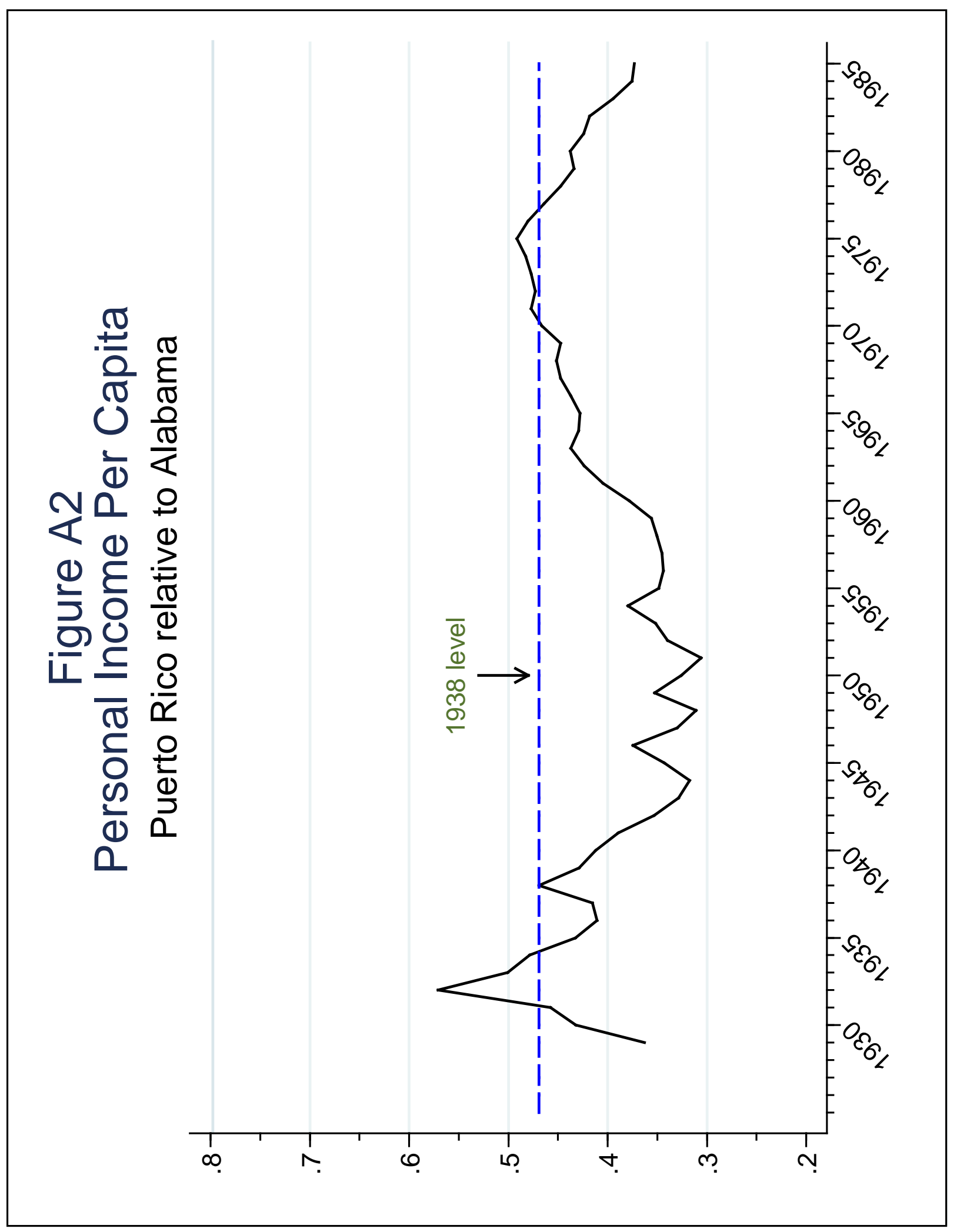




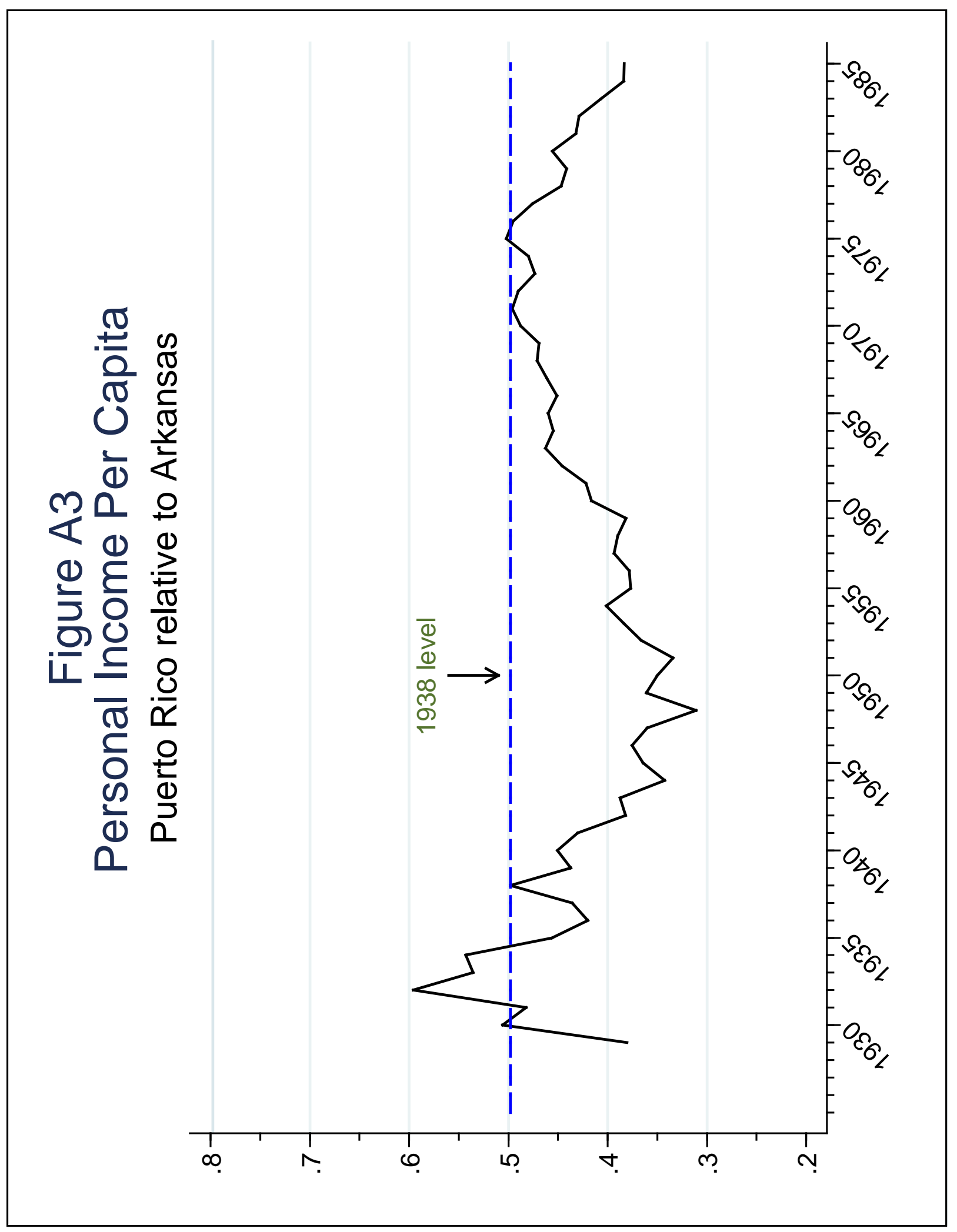

